\title{
Pengaruh Kualitas Layanan Terhadap Kepuasan Pasien Rawat Jalan Tingkat Lanjutan Di Rumah Sakit Umum St. Madyang Kota Palopo
}

\author{
Aswin Agustiansyah', Abdul Rahman Mus², Mahfudnurnajamuddin ${ }^{3}$ \\ ${ }^{1}$ BPJS Kesehatan, Mahasiswa Program Magister Ilmu Manajemen, Universitas Muslim Indonesia \\ 2 Program Magister Ilmu Manajemen, Universitas Muslim Indonesia \\ ${ }^{3}$ Fakultas Ekonomi dan Bisnis, Universitas Muslim Indonesia \\ Email Korespondensi: aswin.agustiansyah@bpjs-kesehatan.go.id
}

\begin{abstract}
Abstrak
Tujuan penelitian ini adalah untuk menganalisis pengaruh tampilan fisik terhadap kepuasan pasien rawat jalan tingkat lanjutan di RSU St Madyang Kota Palopo; menganalisis pengaruh kehandalan terhadap kepuasan pasien rawat jalan tingkat lanjutan di RSU St Madyang Kota Palopo; menganalisis pengaruh ketanggapan terhadap kepuasan pasien rawat jalan tingkat lanjutan di RSU St Madyang Kota Palopo; menganalisis pengaruh jaminan terhadap kepuasan pasien rawat jalan tingkat lanjutan di RSU St Madyang Kota Palopo; menganalisis pengaruh empati terhadap kepuasan pasien rawat jalan tingkat lanjutan di RSU St Madyang Kota Palopo; mengetahui variabel yang memiliki pengaruh dominan terhadap kepuasaan pasien rawat jalan tingkat lanjutan di RSU St Madyang Kota Palopo. Studi ini menggunakan pendekatan kuantitatif deskriptid dengan regresi linear sebagai alat uji analisisnya. Selain daripada itu metode pengumpulan data menggunakan kuesioner yang melibatkan 99 responden. Hasil penelitian ini menyatakan bahwa 1). Variabel tampilan fisik berpengaruh tidak signifikan terhadap kepuasan Pasien RJTL RSU St. Madyang di Kota Palopo, artinya tampilan fisik belum mampu meningkatkan secara signifikan kepuasan Pasien RJTL RSU St. Madyang; 2). Variabel kehandalan berpengaruh signifikan dan positif terhadap kepuasan Pasien RJTL RSU St. Madyang di Kota Palopo, artinya semakin baik atau strategi kehandalan maka cenderung akan meningkatkan kepuasan Pasien RJTL RSU St. Madyang; 3) Variabel ketanggapan berpengaruh signifikan dan positif terhadap kepuasan Pasien RJTL RSU St. Madyang di Kota Palopo, artinya semakin baik atau strategi ketanggapan maka cenderung akan meningkatkan kepuasan Pasien RJTL RSU St. Madyang; 4). Variabel jaminan berpengaruh tidak signifikan terhadap kepuasan Pasien RJTL RSU St. Madyang di Kota Palopo, artinya jaminan belum mampu meningkatkan secara signifikan kepuasan Pasien RJTL RSU St. Madyang. 5). Variabel empati berpengaruh signifikan dan positif terhadap kepuasan Pasien RJTL RSU St. Madyang di Kota Palopo, artinya semakin baik atau strategi ketanggapan maka cenderung akan meningkatkan kepuasan Pasien RJTL RSU St. Madyang; 6). Dari kelima variabel bebas yang digunakan dalam menentukan tingkat kepuasan Pasien RJTL RSU St. Madyang diatas, yang mempunyai pengaruh dominan dalam meningkatkan kepuasan Pasien RJTL di RSU St. Madyang Kota Palopo adalah Variabel Ketanggapan.
\end{abstract}

Kata Kunci: Tampilan Fisik, Kehandalan, Ketanggapan, Jaminan, Empati

\section{Pendahuluan}

Pembangunan kesehatan merupakan bagian integral dari pembangunan nasional yang berlandaskan Pancasila sebagai landasan idiil dan Undang-Undang Dasar 1945 sebagai landasan konstitusional. Dalam Undang-Undang No. 36 Tahun 2009 tentang Kesehatan ditetapkan bahwa kesehatan adalah keadaan sejahtera dari badan, jiwa dan sosial yang memungkinkan setiap orang hidup produktif secara sosial dan ekonomi. Sedangkan dalam konstitusi Organisasi Kesehatan Sedunia (WHO) tahun 1948 ditetapkan antara lain bahwa diperolehnya derajat kesehatan yang setinggitingginya adalah hak yang fundamental bagi setiap orang tanpa membedakan ras, agama, politik yang dianut dan tingkat sosial ekonominya. Untuk menghasilkan derajat kesehatan yang optimal, maka aspek produksi pelayanan kesehatan (supply) dan aspek konsumsi (demand) perlu mendapat perhatian. Penyelenggaraan pelayanan kesehatan diatur oleh pemerintah dan dilakukan oleh pemerintah dan swasta. Tujuan kegiatan ini adalah untuk menyelenggarakan upaya kesehatan yang 
bermutu, merata, dan terjangkau oleh masyarakat yang berpenghasilan rendah. Oleh karena itu, pengelolaan rumah sakit sudah dituntut untuk meningkatkan kualitas produk/jasa pelayanan kepada masyarakat.

Masalah kesehatan bagi masyarakat telah menjadi suatu kebutuhan utama. Kebutuhan yang dimaksud adalah untuk mendapatkan pelayanan kesehatan. Seiring dengan keadaan sosial masyarakat yang semakin meningkat, dimana masyarakat semakin sadar kualitas atau mutu pelayanan kesehatan yang lebih berorientasi pada kepuasan konsumen. Artinya berupaya untuk memberikan pelayanan yang terbaik dan mengevaluasi berdasarkan sudut pandang konsumen. Salah satu lembaga kesehatan yang menangani masyarakat adalah rumah sakit. Rumah sakit adalah bentuk organisasi pengelola jasa pelayanan invidual secara menyeluruh yang padat karya dan padat modal. Di dalam organisasinya terdapat banyak aktivitas, yang diselenggarakan oleh berbagai jenis profesi, baik profesi medik maupun non-medik. Untuk dapat menjalankan fungsinya, diperlukan suatu sistem manajemen rumah sakit termasuk upaya peningkatan kepuasan pasien dan memberikan pelayanan kesehatan yang bermutu yang masih perlu mendapat perhatian terutama pemanfaatan fasilitas kesehatan rumah sakit. Fungsi rumah sakit sekarang ini bertambah ke arah pelayanan kesehatan yang menyeluruh. Fungsi ini meliputi upaya penyembuhan bagi pasien yang sakit maupun yang membutuhkan konsultasi kesehatan dan upaya pencapaian serta peningkatan kesehatan. Untuk itu, rumah sakit dituntut untuk selalu menjaga kepercayaan dengan meningkatkan kualitas pelayanan agar kepuasan pasien meningkat, termasuk Rumah Sakit Umum ST Madyang Kota Palopo.

Rumah Sakit Umum St Madyang Kota Palopo memiliki sembilan layanan unggulan yakni Pelayanan Emergency Kebidanan dan Kandungan 24 Jam (PONEK), Pelayanan Emergensi Neonatus dan Bayi Baru Lahir (Perinatologi), USG jantung, funcsional Endoscopy Sinus Surgery (FESS), Klinik Kecantikan (Skin Clinic), pelayanan radiologi gigi dan mulut (Panoramic), pelayanan spesialis bedah mulut dan gigi serta ortodonsia, operasi mata, dan rehabilitasi medik. Kesembilan layanan tersebut, empat di antaranya hanya ada di RSU St Madyang atau jarang ada di rumah sakit lain di wilayah Luwu Raya, seperti layanan dokter sub spesialis bedah mulut, dokter spesialis jantung yang sudah memiliki peralatan USG jantung, alat operasi sinusitis hidung yakni FESS, dan panoramic hanya ada di RSU St Madyang Kota Palopo. RSU St Madyang Kota Palopo juga perlu menyusun strategi yang dapat merangsang kearah peningkatan pendapatan rumah Sakit. Jika pelanggan merasa puas atas pelayanan dari pihak Rumah Sakit, dimana kepentingan dan harapannya selalu terpenuhi, maka akan didapatkan pelanggan loyal yang pada akhirnya dapat meningkatkan penerimaan Rumah Sakit. Hasil penilaian tingkat kepuasan pelanggan akan dapat memperlihatkan model bagaimana menjadikan pelanggan dapat merasa puas atau tidak puas.

Kualitas memiliki hubungan yang sangat erat dengan pelanggan dalam hal ini pasien rawat jalan tingkat lanjutan. Kualitas yang diberikan oleh pihak rumah sakit akan memberikan dorongan kepada pasien untuk menjalin ikatan hubungan yang kuat sehingga akan berdampak jangka panjang bagi rumah sakit. Ikatan seperti ini memungkinkan rumah sakit memahami dengan seksama harapan dan kebutuhan pasien. Dengan demikian, rumah sakit dapat meningkatkan kepuasan pasien karena mampu memaksimumkan bahkan meniadakan pengalaman pasien yang tidak menyenangkan, sehingga pada gilirannya kepuasan pasien akan terwujud. Dalam meningkatkan kualitas pelayanan, terlebih dahulu harus diketahui apakah kualitas pelayanan Rumah Sakit yang diberikan kepada pasien selama ini telah sesuai dengan harapan. Rumah Sakit dapat mengetahui kualitas pelayanan dari para pasien melalui umpan balik yang diberikan pasien kepada rumah sakit tersebut sehingga dapat menjadi masukan untuk peningkatan kualitas pelayanan. Langkah pertama yang dilakukan agar dapat menentukan kebijakan yang tepat adalah mengetahui dimensi kualitas pelayanan. Menurut (Tjiptono, 2005) kualitas yang dimaksud adalah reliability (kehandalan), responsiveness (daya tanggap), assurance (jaminan), empathy (empati), dan tangible (bukti fisik).

Menyadari akan pentingnya kualitas pelayanan yang diberikan, tim pelayanan keperawatan di Rumah Sakit memberikan pelayanan kepada klien sesuai dengan keyakinan profesi dan standar yang ditetapkan. Hal ini ditujukan agar pelayanan keperawatan yang diberikan senantiasa merupakan pelayanan yang aman serta dapat memenuhi kebutuhan dan harapan klien. Disisi lain perawat diharapkan perannya untuk selalu berada di samping tempat tidur klien, klien menginginkan perawat yang melayaninya memiliki sikap baik, murah senyum serta berkeinginan menolong yang tulus dan mampu menghargai kliennya. Namun demikian, masih banyak ditemukan keluhan klien tentang perawat yang kurang ramah, kurang tanggap dan kurang kompeten. Permasalahan yang terjadi RSU 
St Madyang Kota Palopo yaitu masih adanya kendala terkait dengan pelayanan kesehatan yang harus dihadapi oleh para pasien ketika ingin mendapatkan pelayanan kesehatan, seperti kekosongan obat, waktu tunggu antrian layanan dan informasi signage layanan serta pengaduan ketika pasien mengalami hambatan dalam layanan. RSU St Madyang Kota Palopo sebagai unit pelaksana kesehatan mempunyai visi menjadi rumah sakit yang memiliki kesehatan prima dengan misi memberikan pelayanan bermutu dengan biaya terjangkau kepada semua lapisan masyarakat. RSU St Madyang Kota Palopo yang merupakan salah satu rumah sakit swasta di Kota Palopo dituntut memberikan pelayanan kesehatan yang memuaskan kepada pasien. Kepuasan pelayanan kesehatan di rumah sakit tersebut dicerminkan sebagai pelayanan jasa kesehatan dalam rangka memenuhi kebutuhan pasien sebagai pemakai jasa pelayanan rumah sakit.

Memberikan pelayanan dengan memuaskan, bukanlah sesuatu yang mudah bagi pengelola rumah sakit karena pelayanan yang diberikan rumah sakit menyangkut kualitas hidup para pasiennya, sehingga bila terjadi kesalahan dalam tindakan medis dapat berdampak buruk bagi pasien. Oleh karena itu, rumah sakit dituntut untuk dapat meningkatkan penyediaan fasilitas dan kualitas pelayanan serta melengkapi diri supaya senantiasa mendengarkan keluhan pasien dan memiliki kemampuan memberikan respons terhadap setiap keinginan, harapan dan tuntutan penggguna jasa sarana pelayanan kesehatan. Pelayanan kesehatan dalam menghadapi era globalisasi, berupaya meningkatkan kualitas pelayanan kepada masyarakat. Hal ini disebabkan karena kualitas pelayanan dapat digunakan sebagai alat untuk mencapai keunggulan kompetitif. Implementasi kualitas pelayanan kesehatan masyarakat dilakukan dengan cara memberikan pelayanan (service) terbaik bagi konsumen dengan tujuan menciptakan kepuasan pasien.

Mutu pelayanan adalah suatu pelayanan yang diberikan kepada pasien oleh tenaga kesehatan (tenaga paramedis) secara profesional dengan empati, respek serta tanggap akan kebutuhan pasien untuk meningkatkan derajat kesehatan pasien sesuai dengan ilmu pengetahuan, ketrampilan dan standar yang berlaku. Sedangkan kepuasan adalah suatu keadaan dimana keinginan, harapan dan kebutuhan terpenuhi. Dengan memberikan pelayanan yang bermutu diharapkan dapat meningkatkan kepuasan pasien. Permenkes RI No.: 340/MENKES/PER/III/2010 tentang Klasifikasi Rumah Sakit. Bahwa untuk melaksanakan ketentuan Pasal 24 UU Nomor: 44 Tahun 2009 tentang Rumah Sakit, perlu mengatur Klasifikasi Rumah Sakit dengan PERMENKES. Permenkes tentang Klasifikasi Rumah Sakit Umum berdasarkan Fasilitas dan Kemampuan Pelayaan. Rumah Sakit Umum diklasifikasi menjadi: Rumah Sakit Umum Kelas A, Rumah Sakit Umum Kelas B, Rumah Sakit Umum Kelas C dan Rumah Sakit Umum Kelas D. Pendapat Dirjen Medik Depkes RI (1995) mengatakan bahwa untuk menilai tingkat keberhasilan adalah memberikan gambaran tentang keadaan pelayanan di Rumah Sakit biasanya dilihat dari berbagai segi yaitu: tingkat pemanfaatan sarana pelayanan, mutu pelayanan, tingkat efisiensi pelayanan sehingga dibutuhkan indikator untuk menjadi tolok ukur penilaian diatas. Citra kualitas yang baik bukanlah berdasarkan sudut pandang atau persepsi pihak penyedia jasa, melainkan berdasarkan sudut pandang perilaku pelanggan yaitu melalui kepuasan pelanggan. Apabila pelayanan yang diterima atau dirasakan sesuai dengan yang diharapkan, maka kualitas pelayanan dipersepsikan baik dan memuaskan, sehingga melalui kepuasan pelanggan untuk menggunakan jasa dan akhirnya akan merekomendasikan hal itu kepada orang lain.

Dalam penelitian ini ditemukan bahwa penilaian kualitas pelayanan, yaitu: tangibility, reliability, responsiveness, assurance, dan emphaty. Realibility (kehandalan), yaitu kemampuan perawat untuk memberikan pelayanan yang dijanjikan dengan tepat waktu dan memuaskan. Reponsiveness (ketanggapan), yaitu kemampuan para perawat untuk membantu pasien dan memberikan pelayanan yang tanggap. Emphaty (empati), mencakup kemudahan da lam melakukan hubungan komunikasi yang baik dan memahami kebutuhan para pasien. Assurance (jaminan), mencakup kemampuan, kesopanan, dan sifat dapat dipercaya yang dimiliki para tenaga keperawatan, bebas dari bahaya, risiko atau keragu-raguan. Tangibility (tampilan fisik) meliputi fasilitas fisik perlengkapan, pegawai dan sarana komunikasi. Adanya penilaian kulitas pelayanan di atas, maka pelayanan kesehatan diharapkan tetap dapat berdiri dan semakin berkembang. Kualitas pelayanan yang diberikan petugas kesehatan akan menimbulkan persepsi pasien terhadap pelayanan yang telah diberikan kepada pasien termasuk pasien rawat jalan. Seringkali terdapat perbedaan antara harapan pasien rawat jalan dengan pelayanan yang diberikan oleh petugas kesehatan. Untuk mengetahui apakah petugas kesehatan telah memberikan pelayanan yang sesuai dengan harapan pasien rawat jalan, maka perlu dilakukan evaluasi dari pasien rawat jalan. 
Kualitas pelayanan mempengaruhi pasien dalam menggunakan jasa pelayanan. Untuk memenuhi kepuasan pasien pada organisasi, maka kualitas pelayanan sangat penting dikelola dengan baik. Dengan kualitas pelayanan yang baik, tentunya pasien akan merasa puas dan dengan kepuasan itu tentunya pasien akan mengambil suatu kuputusan untuk menggunakan jasa tersebut. Kepuasan pasien dapat tercipta dengan adanya kualitas jasa pelayanan yang baik dengan kata lain semakin tinggi tingkat kualitas pelayanan maka semakin besar pula kepuasan pasien yang dirasakan dan sebaliknya semakin rendah tingkat kualitas pelayanan maka semakin kecil kepuasan pasien yang dirasakan. Penyelenggaraan kesehatan di RSU St Madyang Kota Palopo masih jauh dari harapan, dimana masih ada keluhan dari beberapa pengguna jasa rumah sakit termasuk pasien rawat jalan yang menyatakan bahwa pelayanan masih lamban, adanya perilaku petugas perawat yang kurang ramah dan tidak komunikatif kepada pasien rawat jalan. Selain itu, peralatan penunjang medis lainnya juga belum memadai sehingga menyebabkan pasien kurang puas dengan pelayanan yang pada akhirnya memberikan pencintraan negatif bagi rumah sakit. Oleh karena itu, strategi yang harus dicapai RSU St Madyang Kota Palopo adalah dengan memberikan pelayanan yang bermutu dan berkualitas serta kemudahan kepada para pasien di rumah sakit sehingga membuat rumah sakit tersebut berbeda dari rumah sakit umum lainnya di Kota Palopo. Kualitas yang tinggi tentunya harus pula didukung oleh kepercayaan pasien akan layanan yang diberikan oleh pihak rumah sakit.

\section{Tabel 1: Rumusan dan Tujuan Penelitian}

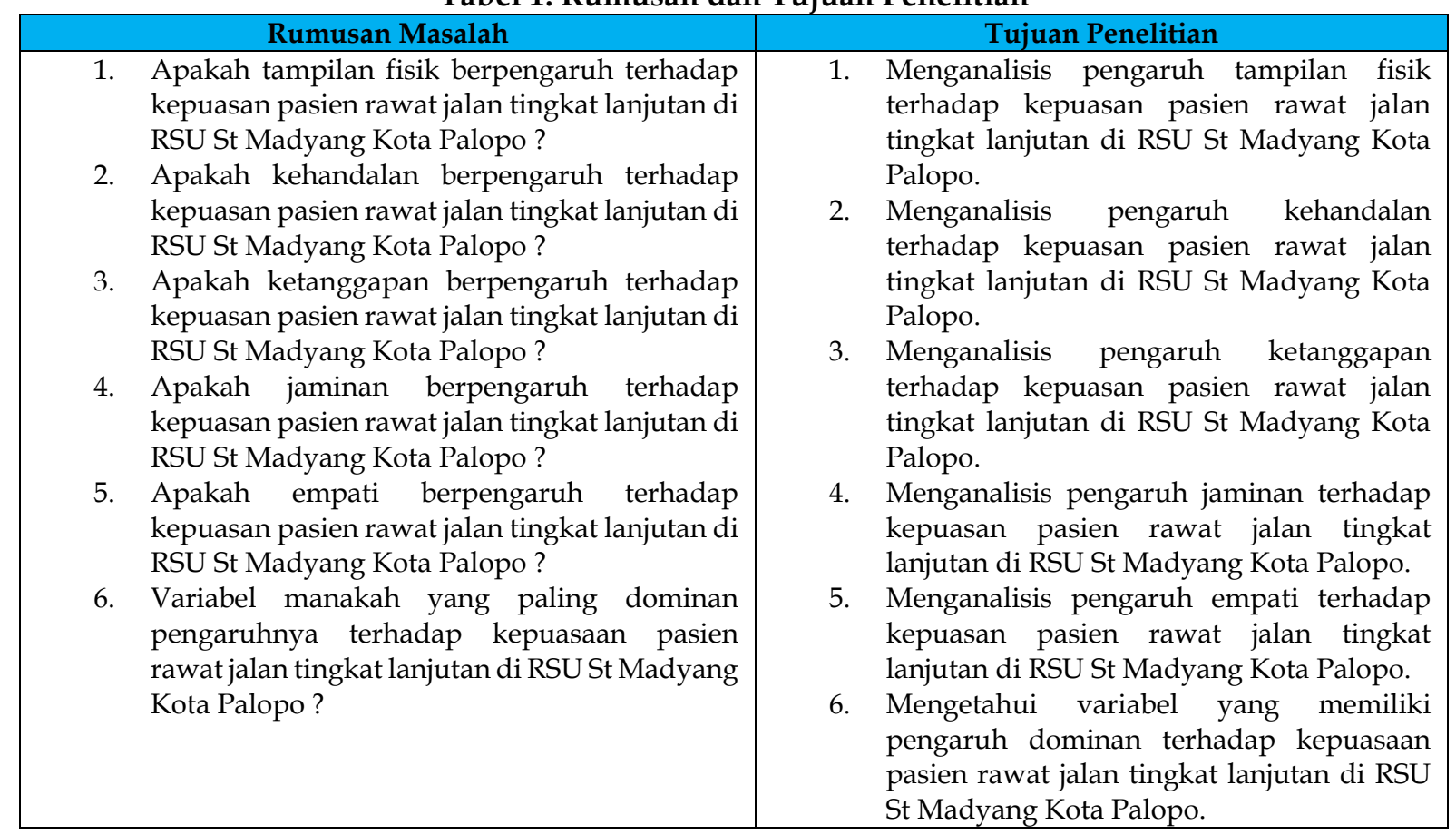

\section{Tinjauan Pustaka}

\section{A. Kualitas Pelayanan}

Kualitas adalah sebuah kata yang bagi penyedia jasa merupakan sesuatu yang harus dikerjakan dengan baik. Menurut Tjiptono (2014:51) mendefinisikan kualitas merupakan suatu kondisi dinamis yang berhubungan dengan produk, jasa, manusia, proses dan lingkungan yang memenuhi atau melebihi harapan. Menurut Buddy (1997) dalam Azrul Azwar (2016:10), kualitas sebagai suatu strategi dasar bisnis yang menghasilkan barang dan jasa yang memenuhi kebutuhan dan kepuasan konsumen internal dan eksternal, secara eksplisit dan implisit. Sedangkan definisi kualitas menurut Marcel (2013:49), adalah seluruh ciri serta sifat suatu produk atau pelayanan yang berpengaruh pada kemampuan untuk memuaskan kebutuhan yang dinyatakan atau yang tersirat. Ini jelas merupakan definisi kualitas yang berpusat pada konsumen, seorang produsen dapat memberikan kualitas bila produk atau pelayanan yang diberikan dapat memenuhi atau melebihi harapan konsumen. Berdasarkan beberapa pengertian kualitas diatas dapat diartikan bahwa kualitas hidup kerja harus 
merupakan suatu pola piker (mindset), yang dapat menterjemahkan tuntutan dan kebutuhan pasar konsumen dalam suatu proses manajemen dan proses produksi barang atau jasa terus menerus tanpa hentinya sehingga memenuhi persepsi kualitas pasar konsumen tersebut.

Menurut American Society for Quality Control, kualitas adalah keseluruhan ciri-ciri dan karakteristik dari suatu produk / jasa dalam hal kemampuannya untuk memenuhi kebutuhan yang telah ditentukan atau bersifat laten (Lupiyoadi, 2011:144). Goetsch dan David dalam Mauludin (2011:39) mengatakan kualitas merupakan suatu kondisi dinamis yang berhubungan dengan produk, manusia, proses dan lingkungan yang memenuhi harapan. Juran dan Wijono dalam Mauludin (2011:39) menyatakan kualitas merupakan perwujudan atau gambaran-gambaran hasil yang mempertemukan kebutuhan-kebutuhan dari pelanggan dalam memberikan kepuasan. Berdasarkan beberapa definisi di atas dapat diambil kesimpulan bahwa kualitas merupakan suatu hasil yang mempertemukan kebutuhan-kebutuhan dari pelanggan dalam memberikan kepuasan dan memenuhi harapan. Untuk memberikan pelayanan yang baik dibutuhkan kesungguhan yang mengandung unsur kecepatan, keamanan, keramahtamahan, dan kenyamanan yang terintegrasi sehingga manfaatnya besar. Pelayanan adalah setiap kegiatan dan manfaat yang dapat diberikan oleh suatu pihak ke pihak lain yang pada dasarnya tidak berwujud dan tidak perlu berakibat pemilikan sesuatu.

Sedangkan pelayanan oleh Gasper dalam Mauludin (2011:39) didefinisikan sebagai aktivitas pada keterkaitan antara pemasok dan pelanggan untuk memenuhi kebutuhan pelanggan. Pelayanan pelanggan yang bermutu membuat pengertian ekonomi sumber kehidupan perusahaan adalah bisnis yang berulang. Meluaskan basis pelanggan adalah vital ini berarti perusahaan tidak harus menarik klien atau pelanggan baru, tetapi juga harus mempertahankan yang sudah ada. Pelayanan pelanggan yang bermutu membuat ini terjadi. Berdasarkan beberapa definisi di atas dapat disimpulkan bahwa pelayanan merupakan suatu tindakan seseorang terhadap orang lain melalui penyajian produk jasa sesuai dengan ukuran berlaku pada jasa/produk untuk memenuhi kebutuhan, keinginan dan harapan orang yang dilayani. Definisi kualitas jasa berpusat pada upaya pemenuhan kebutuhan dan keinginan pelanggan serta ketepatan penyampaiannya untuk mengimbangi harapan pelanggan. Menurut Wyckof, Lovelock (1988) dalam Tjiptono (2014: 59) bahwa kualitas jasa adalah tingkat keunggulan yang diharapkan dan pengendalian atas tingkat keunggulan tersebut untuk memenuhi keinginan pelanggan.

Menurut Parasuraman (2001:39) bahwa kualitas pelayanan merupakan ukuran penilaian menyeluruh atas tingkat suatu pelayanan yang baik. Sedangkan Gronroos et.al dalam Martul (2004) mendefinisikan kualitas pelayanan (service quality) sebagai hasil persepsi dari perbandingan antara harapan pelanggan dengan kinerja aktual pelayanan. Berdasarkan definisi di atas dapat disimpulkan bahwa kualitas pelayanan merupakan suatu penilaian terhadap harapan pelanggan dengan hasil kinerja pelayanan. Selanjutnya Elhaitammy dan Parani dalam Sunyoto (2004), mengemukakan tentang pengertian pelayanan jasa yang unggul (Service excellence) yaitu suatu sikap atau cara karyawan dalam melayani pelanggan secara memuaskan. asaran dan manfaat dari jasa yang unggul secara garis besar terdapat empat unsur pokok yaitu: kecepatan, ketepatan, keramahan, dan kenyamanan. Keempat unsur pokok tersebut merupakan suatu kesatuan pelayanan yang terintegrasi, artinya pelayanan atau jasa menjadi tidak sempurna bila ada salah satu dari unsur tersebut diabaikan. Untuk mencapai hasil yang unggul, setiap karyawan harus memiliki ketrampilan tersebut, di antaranya berpenampilan baik serta berpenampilan ramah, memperlihatkan gairah kerja dan selalu siap melayani, tenang dalam bekerja, tidak tinggi hati karena merasa dibutuhkan, menguasai pekerjaan dengan baik maupun kemampuan untuk berkomunikasi dengan baik, bisa memahami bahasa isyarat dan yang penting adalah mampu menangani keluhan pelanggan secara baik (Supranto, 2007).

\section{B. Bentuk Aktualisasi Kualitas Pelayanan}

Inti dari konsep kualitas pelayanan adalah menunjukkan segala bentuk aktualisasi kegiatan pelayanan yang memuaskan orang-orang yang menerima pelayanan sesuai dengan bukti fisik (tangible) yang dapat dilihatnya, menurut empati (empathy) dari orang-orang yang memberikan pelayanan, kehandalannya (reliability) menjalankan tugas pelayanan yang diberikan secara konsekuen untuk memuaskan yang menerima pelayanan, daya tanggap (responsiveness) dan menumbuhkan adanya jaminan (assurance). Bentuk-bentuk aplikasi kualitas pelayanan yang menerapkan konsep "TERRA" sebagaimana dikemukakan oleh Parasuraman (2001:32) sebagai berikut: (1). Bukti Fisik (Tangible), pengertian bukti fisik dalam kualitas pelayanan adalah bentuk aktualisasi nyata secara fisik dapat terlihat atau digunakan oleh pegawai sesuai dengan penggunaan dan pemanfaatannya yang 
dapat dirasakan membantu pelayanan yang diterima oleh orang yang menginginkan pelayanan, sehingga puas atas pelayanan yang dirasakan, sekaligus menunjukkan kepuasan atas pemberian pelayanan yang diberikan (Parasuraman, 2001:32). Sehubungan dengan memberikan pelayanan, setiap orang yang menginginkan pelayanan dapat merasakan pentingnya bukti fisik yang ditunjukkan oleh pengembang pelayanan, sehingga pelayanan yang diberikan memberikan kepuasan. Bentuk pelayanan bukti fisik biasanya berupa sarana dan prasarana pelayanan yang tersedia, teknologi pelayanan yang digunakan, performance pemberi pelayanan yang sesuai dengan karakteristik pelayanan yang diberikan dalam bentuk pelayanan fisik yang dapat dilihat.

Bentuk-bentuk pelayanan fisik yang ditunjukkan sebagai dimensi kualitas pelayanan dalam rangka meningkatkan kepuasan, merupakan salah satu pertimbangan dalam manajemen organisasi. Menurut Sutojo (2010:49), kepuasan ditunjukkan oleh individu sumberdaya manusia, menjadi penilaian dalam mengaplikasikan aktivitas kerjanya yang dapat dinilai dari bentuk pelayanan fisik yang ditunjukkan. Bentuk pelayanan fisik tersebut berupa kemampuan menggunakan dan memanfaatkan segala fasilitas alat dan perlengkapan di dalam memberikan pelayanan, sesuai dengan kemampuan penguasaan teknologi yang ditunjukkan secara fisik dan bentuk tampilan dari pemberi pelayanan sesuai dengan perilaku yang ditunjukkan. Kualitas pelayanan fisik dalam organisasi terkadang menjadi hal penting dan utama, karena orang yang mendapat pelayanan dapat menilai dan merasakan kondisi fisik yang dilihat secara langsung dari pemberi pelayanan baik menggunakan, mengoperasikan dan menyikapi kondisi fisik suatu pelayanan. Tidak dapat dipungkuri bahwa dalam suatu organisasi modern dan maju, pertimbangan dari para pengembang pelayanan, senantiasa mengutamakan bentuk kualitas kondisi fisik yang dapat memberikan apresiasi terhadap orang yang memberi pelayanan.

Menurut Martul (2014:49), kualitas pelayanan berupa kondisi fisik merupakan bentuk kualitas pelayanan nyata yang memberikan adanya apresiasi membentuk tanggapan positif bagi setiap individu yang dilayani dan menjadi suatu penilaian dalam menentukan kemampuan yang dapat dilihat secara fisik, baik dalam menggunakan alat dan perlengkapan pelayanan, kemampuan menginovasi dan mengadopsi teknologi, dan menunjukkan suatu performance tampilan yang cakap, berwibawa dan memiliki integritas yang tinggi sebagai suatu wujud dari kepuasan yang ditunjukkan kepada orang yang mendapatkan pelayanan. Selanjutnya menurut Margaretha (2013:65), dinamika dunia kerja dewasa ini yang mengedepankan pemenuhan kebutuhan pelayanan masyarakat, maka identifikasi kualitas pelayanan fisik sangat berperan penting dalam memperlihatkan kondisi-kondisi fisik pelayanan tersebut. Identifikasi kualitas pelayanan fisik (tangible) dapat tercermin dari aplikasi lingkungan kerja berupa: a. Kemampuan menunjukkan kepuasan pelayanan dalam menggunakan alat dan perlengkapan kerja secara efisien dan efektif; b. Kemampuan menunjukkan penguasaan teknologi dalam berbagai akses data dan inventarisasi otomasi kerja sesuai dengan dinamika dan perkembangan dunia kerja yang dihadapinya; c. Kemampuan menunjukkan integritas diri sesuai dengan penampilan yang menunjukkan kecakapan, kewibawaan dan dedikasi kerja. Uraian ini secara umum memberikan suatu indikator yang jelas bahwa dimensi kualitas pelayanan sangat ditentukan menurut kondisi fisik pelayanan, yang inti adalah kemampuan dalam menggunakan alat dan perlengkapan kerja yang dapat dilihat secara fisik, menunjukkan kemampuan secara fisik dalam berbagai penguasaan teknologi kerja dan menunjukkan penampilan yang sesuai dengan kecakapan, kewibawaan dan dedikasi kerja.

(2).Empati (Empathy), setiap kegiatan atau aktivitas pelayanan memerlukan adanya pemahaman dan pengertian dalam kebersamaan asumsi atau kepentingan terhadap suatu hal yang berkaitan dengan pelayanan. Pelayanan akan berjalan dengan lancar dan berkualitas apabila setiap pihak yang berkepentingan dengan pelayanan memiliki adanya rasa empati (empathy) dalam menyelesaikan atau mengurus atau memiliki komitmen yang sama terhadap pelayanan (Parasuraman, 2001:40). Empati dalam suatu pelayanan adalah adanya suatu perhatian, keseriusan, simpatik, pengertian dan keterlibatan pihak-pihak yang berkepentingan dengan pelayanan untuk mengembangkan dan melakukan aktivitas pelayanan sesuai dengan tingkat pengertian dan pemahaman dari masing-masing pihak tersebut. Pihak yang memberi pelayanan harus memiliki empati memahami masalah dari pihak yang ingin dilayani. Empati dalam suatu organisasi kerja menjadi sangat penting dalam memberikan suatu kualitas pelayanan sesuai kepuasan yang ditunjukkan oleh seorang pegawai. Empati tersebut mempunyai inti yaitu mampu memahami orang yang dilayani dengan penuh perhatian, keseriusan, simpatik, pengertian dan keterlibatan dalam berbagai permasalahan yang dihadapi orang yang dilayani. Bentuk-bentuk pelayanan ini banyak dikembangkan oleh para pengembang organisasi, 
khususnya bagi pengembang pelayanan modern, yang bertujuan memberikan kualitas pelayanan yang sesuai dengan dimensi empati atas berbagai bentuk-bentuk permasalahan pelayanan yang dihadapi oleh yang membutuhkan pelayanan, sehingga dengan dimensi empati ini, seorang pegawai menunjukkan kualitas pelayanan sesuai dengan kepuasan yang ditunjukkan.

(3).Kehandalan (Reliability), setiap pelayanan memerlukan bentuk pelayanan yang handal, artinya dalam memberikan pelayanan, setiap pegawai diharapkan memiliki kemampuan dalam pengetahuan, keahlian, kemandirian, penguasaan dan profesionalisme kerja yang tinggi, sehingga aktivitas kerja yang dikerjakan menghasilkan bentuk pelayanan yang memuaskan, tanpa ada keluhan dan kesan yang berlebihan atas pelayanan yang diterima oleh masyarakat (Parasuraman, 2001:48). Tuntutan kehandalan pegawai dalam memberikan pelayanan yang cepat, tepat, mudah dan lancar menjadi syarat penilaian bagi orang yang dilayani dalam memperlihatkan aktualisasi kerja pegawai dalam memahami lingkup dan uraian kerja yang menjadi perhatian dan fokus dari setiap pegawai dalam memberikan pelayanannya. Inti pelayanan kehandalan adalah setiap pegawai memiliki kemampuan yang handal, mengetahui mengenai seluk belum prosedur kerja, mekanisme kerja, memperbaiki berbagai kekurangan atau penyimpangan yang tidak sesuai dengan prosedur kerja dan mampu menunjukkan, mengarahkan dan memberikan arahan yang benar kepada setiap bentuk pelayanan yang belum dimengerti oleh masyarakat, sehingga memberikan dampak positif atas pelayanan tersebut yaitu pegawai memahami, menguasai, handal, mandiri dan profesional atas uraian kerja yang ditekuninya (Parasuraman, 2001:101).

Kaitan dimensi pelayanan reliability (kehandalan) merupakan suatu yang sangat penting dalam dinamika kerja suatu organisasi. Kehandalan merupakan bentuk ciri khas atau karakteristik dari pegawai. Kehandalan dalam pemberian pelayanan dapat terlihat dari kehandalan memberikan pelayanan sesuai dengan tingkat pengetahuan yang dimiliki, kehandalan dalam terampil menguasai bidang kerja yang diterapkan, kehandalan dalam penguasaan bidang kerja sesuai pengalaman kerja yang ditunjukkan dan kehandalan menggunakan teknologi kerja. Menurut Sunyoto (2014:16), kehandalan dari suatu individu organisasi dalam memberikan pelayanan sangat diperlukan untuk menghadapi gerak dinamika kerja yang terus bergulir menuntut kualitas pelayanan yang tinggi sesuai kehandalan individu pegawai. Kehandalan dari seorang pegawai yang berprestasi, dapat dilihat dari: a. Kehandalan dalam memberikan pelayanan yang sesuai dengan tingkat pengetahuan terhadap uraian kerjanya; $b$. Kehandalan dalam memberikan pelayanan yang terampil sesuai tingkat keterampilan kerja yang dimilikinya dalam menjalankan aktivitas pelayanan yang efisien dan efektif; c. Kehandalan dalam memberikan pelayanan yang sesuai dengan pengalaman kerja yang dimilikinya, sehingga penguasaan tentang uraian kerja dapat dilakukan secara cepat, tepat, mudah dan berkualitas sesuai pengalamannya; $d$. Kehandalan dalam mengaplikasikan penguasaan teknologi untuk memperoleh pelayanan yang akurat dan memuaskan sesuai hasil output penggunaan teknologi yang ditunjukkan.

Berdasarkan uraian tersebut di atas, maka dapat dipahami bahwa dimensi kualitas pelayanan dari kehandalan dalam suatu organisasi dapat ditunjukkan kehandalan pemberi pelayanan sesuai dengan bentuk-bentuk karakteristik yang dimiliki oleh pegawai tersebut, sesuai dengan keberadaan organisasi. Seorang pegawai dapat handal apabila tingkat pengetahuannya digunakan dengan baik dalam memberikan pelayanan yang handal, kemampuan keterampilan yang dimiliki diterapkan sesuai dengan penguasaan bakat yang terampil, pengalaman kerja mendukung setiap pegawai untuk melaksanakan aktivitas kerjanya secara handal dan penggunaan teknologi menjadi syarat dari setiap pegawai yang handal untuk melakukan berbagai bentuk kreasi kerja termasuk memecahkan berbagai permasalahan kerja yang dihadapinya secara handal.

(4). Daya Tanggap (Responsiveness), setiap pegawai dalam memberikan bentuk-bentuk pelayanan, mengutamakan aspek pelayanan yang sangat mempengaruhi perilaku orang yang mendapat pelayanan, sehingga diperlukan kemampuan daya tanggap dari pegawai untuk melayani masyarakat sesuai dengan tingkat penyerapan, pengertian, ketidaksesuaian atas berbagai bentuk pelayanan yang tidak diketahuinya. Hal ini pula memerlukan adanya penjelasan yang bijaksana, mendetail, membina, mengarahkan dan membujuk agar menyikapi segala bentuk-bentuk prosedur dan mekanisme kerja yang berlaku dalam satu organisasi, sehingga bentuk pelayanan mendapat respon positif (Parasuraman, 2001:52). Tuntutan pelayanan yang menyikapi berbagai keluhan dari bentukbentuk pelayanan yang diberikan menjadi suatu respek positif dari daya tanggap pemberi pelayanan dan yang menerima pelayanan. Seyogyanya pihak yang memberikan pelayanan apabila menemukan orang yang dilayani kurang mengerti atas berbagai syarat prosedur atau mekanisme, maka perlu 
diberikan suatu pengertian dan pemahaman yang jelas secara bijaksana, berwibawa dan memberikan berbagai alternatif kemudahan untuk mengikuti syarat pelayanan yang benar, sehingga kesan dari orang yang mendapat pelayanan memahami atau tanggap terhadap keinginan orang yang dilayani.

Pada prinsipnya, inti dari bentuk pelayanan yang diterapkan dalam suatu instansi atau aktivitas pelayanan kerja yaitu memberikan pelayanan sesuai dengan tingkat ketanggapan atas permasalahan pelayanan yang diberikan. Kurangnya tanggapan tersebut dari orang yang menerima pelayanan, karena bentuk pelayanan tersebut baru dihadapi pertama kali, sehingga memerlukan banyak informasi mengenai syarat dan prosedur pelayanan yang cepat, mudah dan lancar, sehingga pihak pegawai atau pemberi pelayanan seyogyanya menuntun orang yang dilayani sesuai dengan penjelasan-penjelasan yang mendetail, singkat dan jelas yang tidak menimbulkan berbagai pertanyaan atau hal-hal yang menimbulkan keluh kesah dari orang yang mendapat pelayanan. Apabila hal ini dilakukan dengan baik, berarti pegawai tersebut memiliki kemampuan daya tanggap terhadap pelayanan yang diberikan dengan optimal sesuai tingkat kecepatan, kemudahan dan kelancaran dari suatu pelayanan yang ditangani oleh pegawai (Parasuraman, 2001:63). Suatu organisasi sangat menyadari pentingnya dimensi kualitas pelayanan daya tanggap atas pelayanan yang diberikan.

Setiap orang yang mendapat pelayanan sangat membutuhkan penjelasan atas pelayanan yang diberikan agar pelayanan tersebut jelas dan dimengerti. Untuk mewujudkan dan merealisasikan hal tersebut, maka kualitas pelayanan daya tanggap mempunyai peranan penting atas pemenuhan berbagai penjelasan dalam kegiatan pelayanan kepada masyarakat. Apabila pelayanan daya tanggap diberikan dengan baik atas penjelasan yang bijaksana, penjelasan yang mendetail, penjelasan yang membina, penjelasan yang mengarahkan dan yang bersifat membujuk, apabila hal tersebut secara jelas dimengerti oleh individu yang mendapat pelayanan, maka secara langsung pelayanan daya tanggap dianggap berhasil, dan ini menjadi suatu bentuk keberhasilan kerja. Uraian-uraian di atas menjadi suatu interpretasi yang banyak dikembangkan dalam suatu organisasi kerja yang memberikan dimensi kualitas pelayanan yang sesuai dengan daya tanggap atas berbagai pelayanan yang ditunjukkan. Inti dari pelayanan daya tanggap dalam suatu organisasi berupa pemberian berbagai penjelasan dengan bijaksana, mendetail, membina, mengarahkan dan membujuk. Apabila hal ini dapat diimplementasikan dengan baik, dengan sendirinya dimensi kualitas pelayanan daya tanggap akan menjadi cermin keberhasilan pegawai yang ditunjukkan dalam pelayanannya.

(5). Jaminan (Assunrance), setiap bentuk pelayanan memerlukan adanya kepastian atas pelayanan yang diberikan. Bentuk kepastian dari suatu pelayanan sangat ditentukan oleh jaminan dari pegawai yang memberikan pelayanan, sehingga orang yang menerima pelayanan merasa puas dan yakin bahwa segala bentuk urusan pelayanan yang dilakukan atas tuntas dan selesai sesuai dengan kecepatan, ketepatan, kemudahan, kelancaran dan kualitas pelayanan yang diberikan (Parasuraman, 2001:69). Jaminan atas pelayanan yang diberikan oleh pegawai sangat ditentukan oleh performance atau kinerja pelayanan, sehingga diyakini bahwa pegawai tersebut mampu memberikan pelayanan yang handal, mandiri dan profesional yang berdampak pada kepuasan pelayanan yang diterima. Selain dari performance tersebut, jaminan dari suatu pelayanan juga ditentukan dari adanya komitmen organisasi yang kuat, yang menganjurkan agar setiap pegawai memberikan pelayanan secara serius dan sungguh-sungguh untuk memuaskan orang yang dilayani. Bentuk jaminan yang lain yaitu jaminan terhadap pegawai yang memiliki perilaku kepribadian (personality behavior) yang baik dalam memberikan pelayanan, tentu akan berbeda pegawai yang memiliki watak atau karakter yang kurang baik dalam memberikan pelayanan (Barata, 2013:201). Suatu organisasi sangat membutuhkan adanya kepercayaan memberikan pelayanan kepada orang-orang yang dilayaninya. Untuk memperoleh suatu pelayanan yang meyakinkan, maka setiap pegawai berupaya untuk menunjukkan kualitas pelayanan yang meyakinkan sesuai dengan bentuk-bentuk pelayanan yang memuaskan yang diberikan, bentukbentuk pelayanan yang sesuai dengan komitmen organisasi yang ditunjukkan dan memberikan kepastian pelayanan sesuai dengan perilaku yang ditunjukkan.

Untuk mengukur kualitas pelayanan dikenal dua model, yaitu: 1) Serverf yang menggunakan skala yang hanya menangkap persepsi tentang kinerja; dan 2) Serqual yang menggunakan skala perbandingan antara harapan (expectation) dengan persepsi tentang kinerja (performance). Selanjutnya menurut Susilo (2010:19), kualitas layanan pada dasarnya adalah hasil persepsi yang ada dibenak pelanggan. Persepsi ini terbentuk setelah pelanggan membandingkan antara persepsi kualitas layanan yang mereka terima dengan harapan mereka. Berdasarkan uraian di atas, maka kualitas pelayanan rumah sakit kepada setiap pasien dilakukan sesuai dengan bentuk-bentuk kualitas pelayanan yang 
ditunjukkan dapat dipercaya dan menjadi aktualisasi pencerminan kepuasan pasien yang dapat dicapai atas adanya pelayanan petugas kesehatan.

\section{Kepuasan Pasien}

Kepuasan adalah tingkat perasaan seseorang (pelanggan) setelah membandingkan antara kinerja atau hasil yang dirasakan (pelayanan yang diterima dan dirasakan) dengan yang diharapkannya (Sari, 2008). Menurut Kolter (2013) kepuasan pelanggan adalah perasaan senang atau kecewa seseorang sebagai hasil dari perbandingan antara prestasi atau produk yang dirasakan dan yang diharapkannya. Definisi kepuasan pelanggan masih banyak diperdebatkan setidaknya ada dua tipe yang domain. Disatu pihak, kepuasan pelanggan dipandang sebagai outcome atau hasil yang didapatkan dari pengalaman konsumsi barang atau jasa spesifik (outcome-oriented approach). Di lain pihak, kepuasan pelanggan juga kerapkali dipandang sebagai proses (processoriented approach). Kendati demikian, belakangan ini prosess-oriented approach lebih dominan. Penyebabnya, orientasi program dipandang lebih mampu mengungkap pengalaman konsumsi secara keseluruhan dibandingkan orientasi hasil. Orientasi proses menekankan perseptual, evaluatif, dan psikologis yang berkontribusi terhadap terwujudnya kepuasan atau ketidakpuasan pelanggan, sehingga masing-masing komponen signifikan dapat ditelaah secara lebih spesifik (Marknesis, 2009). Definisi kepuasan/ketidakpuasan pelanggan menurut Day dalam Rangkuti (2013), kepuasan pelanggan adalah respon pelanggan terhadap evaluasi ketidaksesuaian (disconfirmation) yang dirasakan antara harapan sebelumnya (atau norma kinerja lainnya) dan kinerja aktual produk yang dirasakan setelah pemakaiannya. Sedangkan ketidakpuasan timbul apabila hasil yang diperoleh tidak memenuhi harapan pelanggan.

Kepuasan adalah sebagai tingkat perasaan seseorang setelah membandingkan kinerja/hasil yang dirasakan dengan harapannya. Karena itu tingkat kepuasan adalah fungsi dari perbedaan kinerja/hasil yang dirasakan dengan harapan. Dengan demikian pelanggan dapat merasakan hal-hal berikut: 1) kalau kinerja di bawah harapan maka pelanggan akan kecewa; 2) kalau kinerja sesuai harapan maka pelanggan merasa puas; dan 3) kalau kinerja melebihi harapan maka pelanggan merasa sangat puas, senang dan gembira (Lerbin, 2015:89). Menurut Handi (2012:68), kepuasan seseorang (pekerja, pasien, dan pelanggan) berarti terpenuhinya kebutuhan yang diinginkan yang diperoleh dari pengalaman melakukan sesuatu pekerjaan atau memperoleh perlakuan tertentu dan memperoleh sesuatu sesuai kebutuhan yang diinginkan. Istilah kepuasan digunakan untuk menganalisis atau mengevaluasi hasil, membandingkan kebutuhan yang diinginkan yang ditetapkan individu dengan kebutuhan yang diperolehnya. Menurut Fraser (2002) dalam Rahmulyono (2018), kepuasan selalu dinyatakan rerata hasil perbandingan dari beberapa keadaan pada suatu saat tertentu. Kepuasan itu berdimensi banyak bersifat tidak mutlak dan skalanya tidak terbatas. Dengan demikian, pada suatu saat tertentu seseorang dapat merasa puas pada suatu aspek dari suatu keadaan. Selanjutnya menurut Fatah (2015) bahwa kepuasan didefinisikan sebagai evaluasi pasca konsumsi bahwa suatu alternatif yang dipilih setidaknya memenuhi atau melebihi harapan. Ketidakpuasan tentu saja didefinisikan sebagai hasil dari suatu harapan yang diteguhkan secara negatif.

Berdasarkan uraian tersebut di atas, maka dapat disimpulkan bahwa kepuasan dicapai apabila pelanggan dalam hal ini pasien memperoleh pelayanan sesuai dengan kebutuhan dan harapan. Untuk menciptakan kepuasan pasien, pihak rumah sakit harus menciptakan dan mengelola sistem untuk memperoleh pelanggan yang lebih banyak dan kemampuan untuk mempertahankan pelanggannya. Pelanggan akan merasa puas jika mereka mendapat produk dan jasa yang memenuhi kebutuhan mereka pada waktu yang tepat dan dengan harga yang dipandang sesuai dengan pelanggan. Konsep kepuasan pelayanan di rumah sakit menurut Azwar (2016), selaras dengan konsep kepuasan yang dikembangkan oleh Wexley dan Yuki dalam Barnes (2013), seseorang terpuaskan jika tidak ada selisih antara kondisi yang dibutuhkan dengan kondisi aktual. Semakin besar kekurangan dalam banyak hal penting yang dibutuhkan, maka semakin besar rasa ketidakpuasan. Ketidakpuasan/ keluhan konsumen terhadap jasa pelayanan karena tidak sesuai dengan yang diharapkan dapat berdampak negatif terhadap keberhasilan jasa pelayanan tersebut. Determinan utama kepuasan pelayanan di rumah sakit adalah pemenuhan kebutuhan pasien berupa pelayanan kesehatan yang bermutu.

Wijono (2011:36) memberikan arti dari kepuasan pasien yaitu tingkat perasaan seseorang setelah membandingkan performansi yang dirasakan dibanding dengan harapannya. Jadi, tingkat kepuasan merupakan fungsi perbedaan antara kinerja yang dirasakan dengan harapannya. Apabila kinerja di bawah harapan, maka pasien akan kecewa. Bila kinerja sesuai dengan harapan, pasien akan puas. 
Sedangkan bila kinerja melebihi harapan, pasien akan sangat puas. Harapan pasien dapat dibentuk oleh pengalaman masa lampau, dan komentar dari kerabatnya. Pasien yang puas akan setia lebih lama, kurang sensitif terhadap harga dan memberi komentar yang baik tentang organisasi (Yakobalis, 2010). Rumah sakit perlu melakukan pemantauan dan pengukuran terhadap kepuasan pasien karena hal ini telah menjadi hal yang esensial bagi setiap rumah sakit. Langkah tersebut dapat memberikan umpan balik dan masukan bagi keperluan pengembangan dan implementasi strategi peningkatan kepuasan pasien.

Sehubungan dengan kepuasan pasien, maka menurut Handi (2012:144) untuk memperoleh pelayanan kesehatan yang bermutu merupakan bagian dari pemenuhan hak konsumen yang utama yaitu hak untuk terpenuhi kebutuhan dasarnya. Tingkat kepuasan pasien terhadap pelayanan di rumah sakit dapat diartikan sebagai gambaran utuh tingkat kualitas rumah sakit menurut penilaian para pasien. Berdasarkan uraian tersebut di atas, maka dapat disimpulkan bahwa kepuasan pasien rawat jalan tingkat lanjutan dicapai apabila penerima pelayanan memperoleh pelayanan sesuai dengan yang dibutuhkan dan diharapkan. Untuk menciptakan kepuasan pesien rawat jalan, maka pihak rumah sakit harus menciptakan dan mengelola sumber daya yang ada sehingga pasien akan merasa puas jika mendapat pelayanan yang memenuhi harapannya.

\section{Pelayanan Kesehatan Pasien di Rumah Sakit}

Rumah sakit merupakan suatu lembaga yang berfungsi mewujudkan pranata upaya pelayanan kesehatan terbesar pada masyarakat di jaman modern ini. Rumah sakit didirikan sebagai suatu tempat untuk memenuhi berbagai permintaan pasien dan dokter, agar penyelesaian masalah kesehatan dapat dilaksanakan dengan baik. Menurut Wolper dan Pena dalam Azwar (2016:84) rumah sakit adalah tempat dimana orang sakit mencari dan menerima pelayanan kedokteran serta tempat dimana pendidikan kliniks untuk mahasiswa kedokteran, perawat dan berbagai tenaga profesi kesehatan lainnya diselenggarakan. Menurut Ivancevich dalam Ratminto dan Minarsih (2015:2), pelayanan adalah produk-produk yang tidak kasat mata (tidak dapat diraba) yang melibatkan usaha-usaha manusia dan menggunakan peralatan. Sedangkan menurut Gronroos dalam Ratminto dan Minarsih (2015:2) bahwa pelayanan adalah suatu aktivitas atau serangkaian aktivitas yang bersifat tidak kasat mata yang terjadi sebagai akibat adanya interaksi antara konsumen dan petugas atau hal-hal lain yang disediakan oleh perusahaan pemberi layanan yang dimaksudkan untuk memecahkan permasalahan pelanggan.

Sehubungan dengan kualitas pelayanan di rumah sakit, maka menurut Saranga (2010) untuk memperoleh pelayanan kesehatan yang bermutu merupakan bagian dari pemenuhan hak konsumen yang utama yakni terpenuhi kebutuhan dasar. Tingkat kepuasan pelayanan pasien terhadap pelayanan di rumah sakit dapat diartikan sebagai gambaran utuh tingkat kualitas rumah sakit menurut penilaian pasien. Tuntutan masyarakat terhadap kepuasan pelayanan kesehatan pasien telah menjadi masalah mendasar yang dihadapi sebagian besar rumah sakit diberbagai negara. Tuntutan ini menjadi dasar pengembangan organisasi kesehatan dan sistem pelayanan kesehatan di berbagai negara melalui pelaksanaan desentralisasi. Kompleksitas masalah kualitas pelayanan rumah sakit tidak saja terkait dengan keterbatasan sumber daya dan lingkungan, tetapi juga bersumber dari perbedaan persepsi diantara pemakai jasa pelayanan, sumber kesehatan, dan pemerintah atau penyandang dana terhadap ukuran kualitas pelayanan kesehatan di rumah sakit.

Bagian penerimaan pasien di rumah sakit mempunyai pengaruh dan nilai walaupun mungkin belum ada tindakan-tindakan pelayanan medis khusus yang diberikan kepada pasien. Kesan pertama akan memberikan arti tersendiri bagi pasien untuk melalui proses pelayanan selanjutnya. Kesiapan petugas, kelengkapan sarana/prasarana di bagian penerimaan pasien haruslah optimal. Diperlukan petugas-petugas yang mempunyai dedikasi tinggi, seperti: terampil, ramah, sopan, simpati, luwes, penuh pengertian, mempunyai kemampuan komunikasi dengan baik. Organisasi yang baik, diperlukan staf bagian penerimaan pasien yang mempunyai keterampilan tertentu yaitu: pewawancara, pencatat, dapat melakukan koordinasi dengan baik, mempunyai kemampuan umum tentang rumah sakit, menguasai pekerjaannya dan yang lebih penting adalah petugas yang mempunyai kemampuan komunikasi dan interpersonal baik (Wijono, 2011:67). Prosedur kerja yang jelas, tegas dan tersusun rapi, data tempat tidur yang tersedia, tarif serta peralatan-peralatan sesuai standar pelayanan harus tersedia dan benar. Petugas rumah sakit harus memancarkan sikap positif pada orang lain dalam memberikan pelayanan pasien yang berkualitas. 
Pelayanan jasa yang diselenggarakan di rumah sakit untuk melayani kebutuhan masyarakat khususnya di bidang perawatan adalah pelayanan rawat inap dan pelayanan rawat jalan. Pelayanan rawat jalan, pasien memperoleh pelayanan kesehatan pada jam-jam tertentu dan tidak perlu pemondokan, sedangkan pelayanan rawat inap dimana pasien memperoleh pelayanan kesehatan yang berlangsung lebih dari 24 jam. Selama perawatan di ruang rawat inap, pasien akan memperoleh jasa pelayanan berupa pemeriksaan, diagnosa penyakit, pengobatan atau tindakan, asuhan keperawatan, dievaluasi kondisinya, dan akhirnya pasien diperbolehkan keluar dari rumah sakit (sembuh, cacat, meninggal, dirujuk). Ruang rawat inap merupakan tempat yang paling lama bagi pasien untuk tinggal dibanding unit-unit lainnya. Dengan demikian, harapan serta keyakinan pasien untuk memperoleh pelayanan dengan sebaik-baiknya, dimana pihak rumah sakit berusaha semaksimal mungkin dapat memberikan pelayanan sesuai harapan pasien.

Penderita membutuhkan pelayanan kesehatan rumah sakit, maka terpikir pertama kali adalah dokternya, baru kemudian mengharapkan perawatan yang baik dari perawat. Tenaga medik mempunyai pengabdian yang tinggi dalam memberikan pelayanan kepada pasien disertai rasa kasih sayang, penuh perhatian, pengertian, memberikan rasa aman, serta harus berusaha sekuat tenaga dalam mengobati dan merawat pasien. Suatu rumah sakit agar bisa professional, tidak cukup mempunyai sumber daya manusia saja, tetapi harus didukung pula oleh fasilitas penunjang rumah sakit baik penunjang medis maupun non medis serta sarana penunjang rumah sakit seperti: laboratorium, instalasi farmasi, radiologi, pelayanan makan pasien, dan lain-lain. Fasilitas penunjang rumah sakit juga sangat menentukan terhadap kualitas pelayanan rumah sakit. Kualitas pelayanan rumah sakit juga ditentukan oleh lingkungan rumah sakit. Persyaratan kesehatan lingkungan rumah sakit adalah: 1. Lokasi atau lingkungan rumah sakit seperti nyaman, tenang, aman, terhindar dari pencemaran, dan selalu dalam keadaan bersih; 2. Ruangan: berlantai dan berdinding bersih, penerangan cukup, tersedia tempat sampah, bebas bau yang tidak sedap, bebas dari gangguan serangga, tikus dan binatang pengganggu lainnya, penghawaan cukup, dan ventilasi udara yang baik; 3. Atap, langit-langit, pintu sesuai dengan syarat yang telah ditentukan.

Biaya pelayanan kesehatan makin hari semakin meningkat akibat berbagai faktor antara lain: laju inflasi, perubahan pola penyakit, perubahan hubungan dokter pasien, tingkat permintaan yang meningkat, serta penggunaan peralatan kedokteran yang modern. Tarif yang tinggi dapat mengurangi kepuasan pasien sehingga secara tidak langsung akan mengurangi pemanfaatan sarana kesehatan oleh masyarakat khususnya bagi mereka yang mampu. Berdasarkan uraian tersebut di atas, maka dapat disimpulkan bahwa kualitas pelayanan pasien dapat dicapai apabila pasien memperoleh pelayanan sesuai yang dibutuhkan dan diharapkan. Untuk menciptakan kualitas pelayanan pasien, maka pihak rumah sakit harus menciptakan dan mengelola sistem untuk memperoleh pelanggan yang lebih banyak dan kemampuan untuk mempertahankan pelanggannya. Pelanggan akan merasa puas jika mereka mendapat pelayanan yang sesuai dengan harapan dan keinginan pasien pada waktu yang tepat dan dengan harga yang dipandang sesuai kemampuan pasien.

\section{E. Penelitian Terdahulu}

Guna mengungkap berbagai fenomena empiris menyangkut objek kajian dalam penelitian ini, beberapa hasil penelitian akan dijadikan rujukan sekaligus perbandingan dengan penelitian ini, yaitu:

Anis Wahyuningsih (2012) melakukan penelitian dengan judul: Analisa Tingkat Kepuasan Pasien Berdasarkan Kualitas Pelayanan Pada Rumah Sakit Umum Kabupaten Karanganyar. Penelitian ini bertujuan untuk mengetahui dan menganalisis tingkat kepuasan pasien berdasarkan kualitas pelayanan pada Rumah Sakit Umum Kabupaten Karanganyar. Hasil penelitian ini menunjukkan bahwa ada pengaruh yang signifikan antara dimensi kualitas pelayanan dengan tingkat kepuasan pasien, dan kehandalan (reliability) mempunyai pengaruh paling dominan terhadap kepuasan pasien di Rumah Sakit Umum Kabupaten Karanganyar. Purnami Astuti Sari (2016) melakukan penelitian yang berjudul: “Analisis Pengaruh Kualitas Pelayanan Terhadap Kepuasan Pasien di RSUD Kota Bau-Bau Propinsi Sulawesi Tenggara". Penelitian ini bertujuan untuk mengetahui dan menganalisis pengaruh variabel bukti langsung, keandalan, daya tanggap, jaminan, dan empati terhadap kualitas pelayanan pasien di RSUD Kota Bau-Bau. Hasil penelitian menunjukkan bahwa variabel bukti langsung, keandalan, daya tanggap, jaminan, dan empati secara bersama-sama berpengaruh signifikan terhadap kualitas pelayanan pasien di RSUD Kota Bau-Bau. Variabel keandalan memberikan pengaruh yang paling dominan terhadap kualitas pelayanan pasien di RSUD Kota Bau-Bau. 
Agustina (2017) dengan judul "Pengaruh faktor-faktor kualitas pelayanan pada RSUD Kabupaten Kolaka. Penelitian ini bertujuan untuk mengetahui pengaruh pelayanan dokter, pelayanan perawat, dan pelayanan administrasi terhadap kualitas pelayanan pasien di RSUD Kabupaten Kolaka. Hasil penelitian menunjukkan bahwa variabel pelayanan dokter, pelayanan perawat, dan pelayanan administrasi secara bersama-sama berpengaruh signifikan terhadap kualitas pelayanan pasien di RSUD Kabupaten Kolaka. Ridwan (2017) dengan judul "Analisis kualitas pelayanan jasa pada Rumah Sakit Umum Kabupaten Bantaeng". Penelitian ini bertujuan untuk mengetahui pengaruh variabel kecepatan, ketepatan, keamanan, dan keramahan tenaga medis terhadap kualitas pelayanan jasa pada Rumah Sakit Umum Kabupaten Bantaeng. Hasil penelitian menunjukkan bahwa variabel kecepatan, ketepatan, keamanan, dan keramahan tenaga medis secara bersama-sama berpengaruh signifikan terhadap kualitas pelayanan jasa di Rumah Sakit Umum Kabupaten Bantaeng. Berdasarkan sejumlah hasil penelitian tersebut, dapat dijadikan sebagai acuan dan sebagai bahan referensi dalam menganalisis kualitas pelayanan terhadap kepuasan pasien rawat jalan tingkat lanjutan di RSU St Madyang Kota Palopo. Selain itu, dapat melihat adanya perbedaan dan persamaan dari penelitian terdahulu. Tentunya, hasil penelitian ini dapat sama dan dapat berbeda, karena adanya persamaan dan perbedaan dari variabel yang diteliti.

\section{F. Kerangka Konseptual}

Kerangka konseptual yang merupakan hubungan dari ketiga variabel tersebut yaitu kehandalan, ketanggapan dan empati, sebagai berikut.

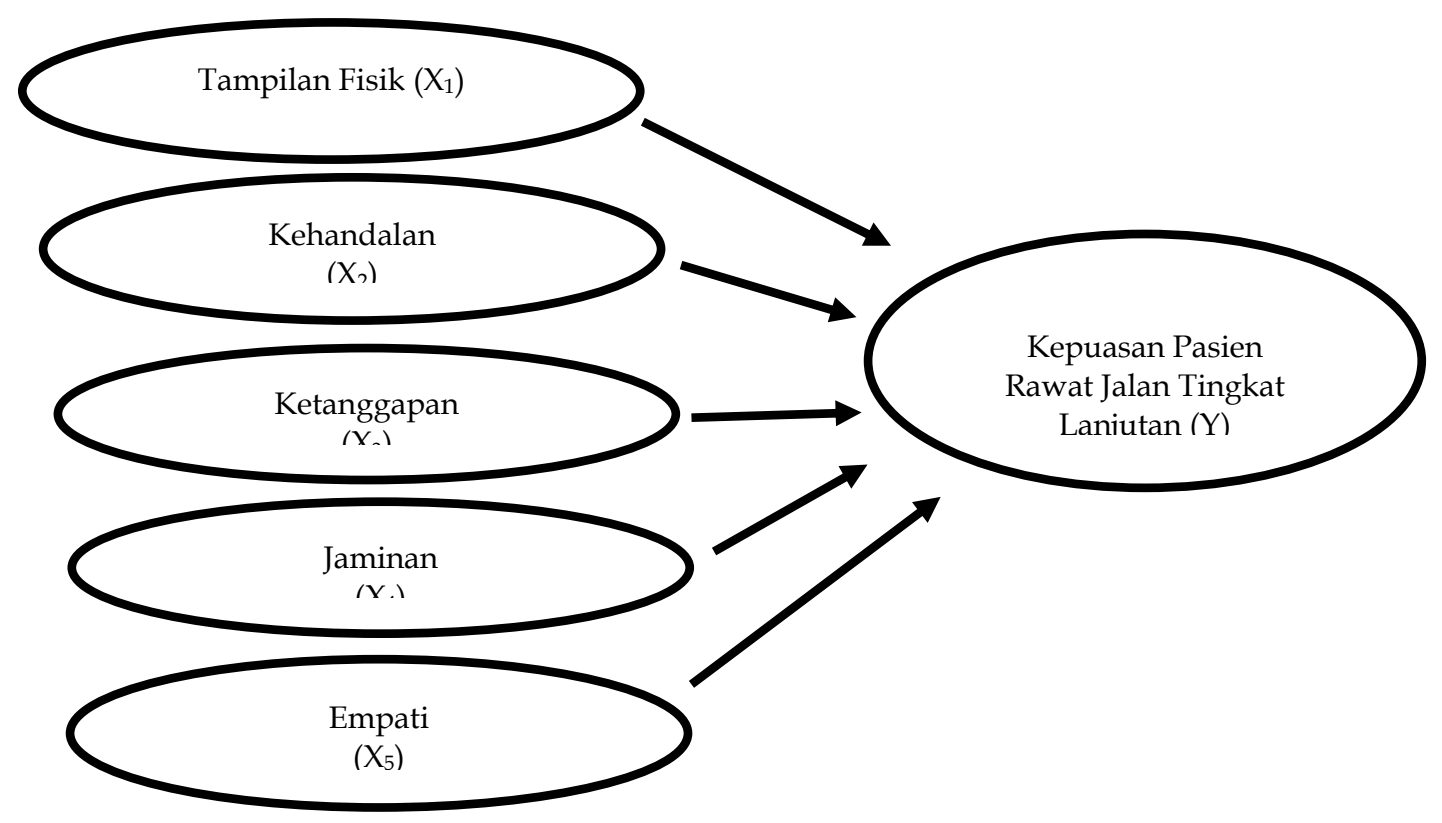

\section{Gambar 1. Kerangka Konseptual}

Berdasarkan rumusan masalah dan kerangka konseptual tersebut di atas, maka hipotesis, yang diajukan dalam penelitian ini adalah:

1. Kualitas pelayanan yang meliputi: kehandalan, ketanggapan, empati, jaminan, dan tampilan fisik berpengaruh signifikan terhadap kepuasan pasien rawat jalan tingkat lanjutan di RSU St Madyang Kota Palopo.

2. Kehandalan yang paling dominan pengaruhnya terhadap kepuasaan pasien rawat jalan tingkat lanjutan di RSU St Madyang Kota Palopo.

\section{Metode Penelitian}

Penelitian ini dilakukan dengan menggunakan pendekatan kuantitatif. Jenis penelitian ini bersifat survei yaitu menganalisis fakta dan data-data yang diperlukan untuk mendukung pembahasan penelitian, dalam memecahkan dan menjawab pokok permasalahan yang diajukan yaitu: menganalisis 
pengaruh kehandalan, ketanggapan, empati, jaminan, dan tampilan fisik terhadap kepuasan pasien rawat jalan tingkat lanjutan di RSU St Madyang Kota Palopo. Lokasi penelitian akan dilaksanakan pada Rumah Sakit Umum St Madyang Kota Palopo. Sedangkan waktu yang dibutuhkan untuk melakukan pengumpulan data yaitu selama lebih kurang 2 bulan yaitu November sampai Desember 2020. Jenis data yang dikumpulkan dalam penelitian ini adalah sebagai berikut Data primer yang diperoleh melalui hasil penelitian langsung terhadap obyek yang diteliti. Data tersebut diperoleh melalui metode wawancara, observasi dan hasil kuesioner dari responden. Data sekunder yang diperoleh dari berbagai sumber, antara lain: dokumentasi, buku-buku, laporan-laporan, karya ilmiah dan hasil penelitian seperti data jumlah pegawai, gambaran umum lokasi penelitian dan lain-lain. Sumber Data diperoleh Rumah Sakit Umum St Madyang Kota Palopo. Responden yakni: pasien rawat jalan tingkat lanjutan.

Metode pengumpulan data yang digunakan dalam penelitian adalah sebagai berikut: 1). Observasi yaitu: melakukan pengumpulan data melalui pengamatan langsung mengenai kepuasan pelayanan pasien dengan mengadakan pendekatan kepada beberapa pasien rawat jalan tingkat lanjutan, perawat dan dokter serta bagian pegawai RSU St Madyang Kota Palopo; 2). Interview yaitu: penulis melakukan tanya jawab kepada para responden secara langsung untuk memperoleh data berkaitan dengan kepuasan pelayanan pasien; 3). Dokumentasi yaitu: penulis mencatat dokumen atau arsip-arsip atau dokumen pada RSU St Madyang Kota Palopo. 4). Kuesioner, yaitu pengumpulan data yang dilakukan dengan cara mengedarkan daftar pertanyaan kepada responden yang disusun sesuai dengan data yang dibutuhkan berdasarkan wawancara dan observasi pendahuluan yang telah dilakukan. Dalam penelitian ini populasi terdiri dari seluruh Pasien Rawat Jalan Tingkat Lanjutan di RSU St. Madyang Kota Palopo. Metode sampling yang digunakan ada dua yaitu purposive sampling dan accidental sampling. Menurut Masri S dan S Effendi (2001), purposive sampling adalah pemilihan sampel yang bersifat tidak acak, di mana sampel dipilih berdasarkan pertimbangan-pertimbangan tertentu, sedangkan accidental sampling adalah siapa saja yang mendapatkan pelayanan kesehatan yang ditemui untuk dijadikan sampel. Metode pengambilan sampel dalam penelitian ini ditentukan sebanyak 99 orang responden pasien RJTL dengan menggunakan teknik accidental sampling dengan pertimbangan mereka mampu memberikan penilaian secara langsung dan objektif terhadap kepuasan layanan yang mereka rasakan di RSU St. Madyang Palopo. Uji validitas data digunakan sebagai alat untuk mengukur sah atau valid tidaknya suatu kuisioner. Suatu kuesioner dapat dikatakan valid atau sah, jika pertanyaan pada kuesioner mampu untuk mengungkapkan sesuatu yang akan diukur oleh kuesioner tersebut dengan menggunakan korelasi bivariate. Menurut Sugiyono (2013) bahwa apabila validitas setiap pertanyaan lebih besar dari 0,30 maka butir pertanyaan dianggap valid. Uji reliabilitas adalah untuk mengukur gejala yang sama dan hasil pengukuran diproses relatif secara konsisten. Menurut Sugiyono (2003) bahwa uji reliabilitas ditentukan dengan koefisien Cronbach's Alpha dengan mensyaratkan suatu instrument yang reliable jika memiliki koefisien Cronbach's Alpha di atas 0,60.

Uji Asumsi Klasik Uji normalitas bertujuan untuk menguji apakah dalam model regresi variabel dependen dan variabel independen, keduanya mempunyai distribusi normal atau tidak. Model regresi yang baik adalah memiliki distribusi data normal atau mendekati normal. Pada prinsipnya normalitas dapat dideteksi dengan melihat penyebaran data (titik) dari nilai residual pada model regresi yang akan diuji. Jika residual berdistribusi normal maka nilai-nilai sebaran data akan terletak di sekitar garis lurus. Uji multikolinearitas bertujuan untuk menguji apakah model regresi ditemukan adanya korelasi bebas (independen). Deteksi terhadap ada tidaknya multikolinearitas yaitu dengan menganalisis matriks korelasi variabel-variabel bebas, dapat juga dengan melihat pada nilai tolerance. Salah satu asumsi dalam regresi berganda adalah uji heterokedastisitas. Uji ini dilakukan untuk menguji apakah dalam model regresi terjadi ketidaksamaan variance dari residual satu pengamatan ke pengamatan lain. Dalam regresi, salah satu asumsi yang harus dipenuhi adalah bahwa varians dari residual satu pengamatan ke pengamatan lain tidak memiliki pola tertentu. Pola yang tidak sama ini ditunjukkan dengan nilai yang tidak sama antar satu varians dari residual yang disebut heterokedastisitas, sedangkan adanya gejala varians residual yang sama dari satu pengamatan ke pengamatan lain disebut homokedastisitas.

Untuk mengolah data hasil penelitian tersebut, maka penulis menggunakan 2 (dua) metode, yakni: 1). Analisis deskriptif, yaitu digunakan untuk menguraikan secara deskriptif karakteristik responden dan variabel-variabel penelitian melalui distribusi frekuensi, rata-rata dan persentase. 2). Analisis regresi linear berganda dalam penelitian ini digunakan untuk mengetahui pengaruh kehandalan, ketanggapan, empati, jaminan, dan tampilan fisik terhadap kepuasan pasien rawat jalan tingkat 
lanjutan pada RSU St Madyang Kota Palopo. Adapun rumus yang digunakan (Sugiyono, 2004:251) adalah

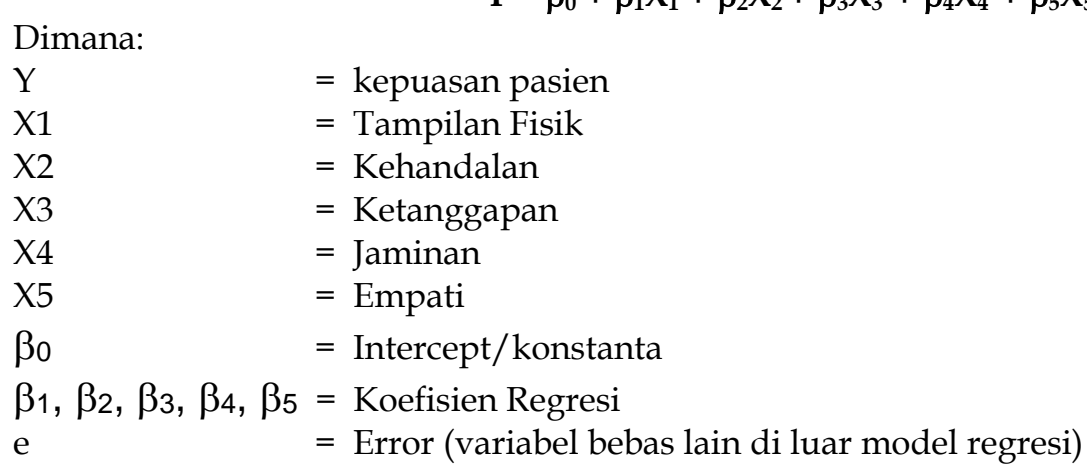

Pengujian Hipotesis dilakukan dengan Uji Simultan ini dilakukan untuk mengetahui apakah semua variabel independent mempunyai pengaruh yang sama terhadap variabel dependent. Untuk membuktikannya kebenaran hipotesis digunakan uji distribusi $\mathrm{F}$ dengan cara membandingkan antara nilai F-hitung (yang terdapat pada tabel Analysis of Variance) dengan nilai F-tabel, apabila perhitungan F-hitung > F-tabel maka Ho ditolak sehingga dapat dikatakan bahwa variabel bebas dari regresi dapat menerangkan variabel terikat secara serentak. Sebaliknya jika Fhitung < Ftabel maka Ho diterima sehingga dapat dikatakan bahwa variabel bebas tidak menjelaskan variabel terikat (Algifari, 2000: 7273). Uji Parsial adalah uji yang digunakan untuk menguji kemampuan koefisien parsial. Apakah thitung > t-tabel maka Ho ditolak, dengan demikian variabel bebas dapat menerangkan variabel berikutnya. Sebaliknya apabila t-hitung $<$ t-tabel maka Ho diterima sehingga dapat dikatakan variabel bebas tidak dapat menjelaskan variabel berikutnya, dengan kata lain tidak ada pengaruh diantara variabel yang diuji. Sedangkan Uji koefisien determinasi (R2) menunjukkan koefisien determinasi yaitu seberapa besar perubahan variabel terikat diakibatkan oleh perubahan variabel bebas secara bersamasama. Semakin besar nilai koefisien determinasi maka semakin besar pula variasi sumbangan bebas terhadap variabel terikat (Algifari, 2000:69). Data penelitian ini dianalisis dengan menggunakan program SPSS (Statistical Product and Service Solutions).

\section{Pembahasan}

a) Karakteristik Responden

Karakteristik responden dapat diketahui dari hasil penelitian yang dilakukan pada seluruh pasien (keluarga pasien) yang mendapatkan pelayanan di RSU St Madyang Kota Palopo yang berjumlah 99 orang responden, yang meliputi: jenis kelamin, tingkat umur, dan tingkat pendidikan. Adapun karakteristik responden, dapat dijelaskan sebagai berikut:

\section{Jenis Kelamin}

Jumlah responden yang digunakan dalam penelitian ini adalah 99 orang, dengan jenis kelamin terdiri atas: laki-laki dan perempuan. Adapun distribusi responden menurut jenis kelamin dapat dilihat pada Tabel 2 berikut ini.

Tabel 2. Distribusi Responden menurut Jenis Kelamin

\begin{tabular}{|c|l|c|r|}
\hline No. & \multicolumn{1}{|c|}{ Jenis Kelamin } & Frekuensi (orang) & Persentase (\%) \\
\hline 1. & Laki-laki & 56 & 56,57 \\
2. & Perempuan & 43 & 43,43 \\
\hline \multicolumn{2}{|c|}{ Jumlah } & 99 & 100,00 \\
\hline
\end{tabular}

Sumber: Data Primer, 2020.

Berdasarkan data pada Tabel 2, dapat dijelaskan bahwa komposisi responden menurut jenis kelamin yang terbanyak adalah jenis kelamin laki-laki yakni 145 orang atau $58 \%$, sedangkan perempuan 105 orang atau $42 \%$. 


\section{Tingkat Umur}

Umur masing-masing responden berada pada interval 28 tahun sampai dengan 55 tahun (Lampiran 2). Tingkat umur tersebut diharapkan mampu memberikan tanggapan yang objektif tentang kepuasan Pasien RJTL RSU St. Madyang di Kota Palopo. Adapun distribusi responden menurut tingkat umur dapat dilihat pada Tabel 3.

Tabel 3. Distribusi Responden menurut Tingkat Umur

\begin{tabular}{|c|c|c|c|}
\hline No. & Tingkat Umur (tahun) & Frekuensi (orang) & Persentase $(\%)$ \\
\hline 1. & $\leq 34$ & 21 & 21,21 \\
\hline 2. & $35-41$ & 40 & 40,40 \\
\hline 3. & $42-48$ & 23 & 23,23 \\
\hline 4. & $\geq 49$ & 15 & 15,15 \\
\hline \multicolumn{2}{|r|}{ Jumlah } & 99 & 100,00 \\
\hline
\end{tabular}

Sumber: Data Primer, 2020.

Berdasarkan data pada Tabel 3 dapat dijelaskan bahwa responden yang memiliki proporsi tingkat umur terbanyak berada pada tingkat umur 35 - 41 tahun yakni 123 orang responden atau $49,20 \%$, dan kemudian diikuti tingkat umur $42-48$ sebanyak 71 orang atau $28,40 \%$, dan tingkat umur 34 tahun ke bawah sebanyak 33 orang atau $13,20 \%$. Sedangkan yang terendah adalah 49 tahun ke atas sebanyak 23 orang atau $9,20 \%$.

\section{Tingkat Pendidikan}

Tingkat pendidkan adalah jenjang pendidikan yang telah ditamati oleh responden sesuai dengan latar belakang pendidikan dan disiplin ilmu yang ditekuninya dan diakui oleh pemerintah. Adapun karakteristik responden menurut tingkat pendidikan pasien di RSU St Madyang Kota Palopo, dapat dilihat pada Tabel 4 .

Tabel 4. Distribusi Responden menurut Tingkat Pendidikan

\begin{tabular}{|c|c|c|c|}
\hline No. & Tingkat Pendidikan & Jumlah (orang) & Persentase $(\%)$ \\
\hline 1. & SD & 8 & 8,08 \\
2. & SLTP & 18 & 18,18 \\
3. & SLTA & 37 & 37,37 \\
4. & Diploma & 9 & 9,10 \\
5. & S1 & 27 & 27,27 \\
\hline \multicolumn{2}{|r|}{} & 99 & 100,0 \\
\hline
\end{tabular}

Sumber: Data Primer, 2020.

Tabel 4 menunjukkan karakteristik responden berdasarkan tingkat pendidikan diperoleh data yang variatif. Data yang terjaring menunjukkan bahwa tingkat pendidikan responden yakni SD sebanyak 21 orang, SLTP sebanyak 47 orang, SLTA sebanyak 94 orang, Diploma sebanyak 23 orang, dan $\mathrm{S} 1$ sebanyak 65 orang.

\section{b) Analisis Deskriptif Variabel Penelitian}

Variabel yang digunakan dalam penelitian ini adalah kepuasan pasien $(Y)$ sebagai variabel terikat dan tampilan fisik (X1), kehandalan (X2), ketanggapan (X3), jaminan (X4), dan empati (X5) sebagai variabel bebas. Adapun masing-masing variabel tersebut akan dijelaskan sebagai berikut:

\section{Kepuasan Pasien RJTL (Y)}

Kepuasan pasien RJTL $(Y)$ adalah tingkat perasaan seseorang setelah membandingkan antara sesuatu yang menjadi harapannya dengan sesuatu yang telah ia terima setelah mendapatkan pelayanan administrasi dari RSU St Madyang Palopo. Indikator yang digunakan adalah: 1) senang dengan pelayanan dari petugas RS; 2) Pelayanan yang diberikan sesuai dengan harapan pasien; dan 3) Sikap profesional petugas RS. bAdapun distribusi frekuensi tanggapan responden tentang variabel kepuasan pasien di RSU St Madyang Palopo dapat dilihat pada tabel berikut ini. 
Tabel 5. Deskripsi variabel kepuasan Pasien RJTL RSU St. Madyang

\begin{tabular}{|c|c|c|c|c|c|c|}
\hline \multirow{2}{*}{ Indikator } & \multicolumn{5}{|c|}{ Frekuensi Jawaban (orang)/(\%) } & \multirow{2}{*}{ Mean } \\
\hline & STS & TS & CS & $\mathrm{S}$ & SS & \\
\hline $\begin{array}{l}\text { Pasien merasa aman saat mendapat pelayanan } \\
\text { kesehatan }\end{array}$ & 0 & 0 & 4 & 35 & 60 & 4,57 \\
\hline $\begin{array}{l}\text { Pelayanan yang diberikan Petugas sudah sesuai } \\
\text { harapan pasien }\end{array}$ & 0 & 0 & 13 & 35 & 51 & 4,38 \\
\hline Sikap profesional petugas RS & 0 & 0 & 4 & 20 & 75 & 4,72 \\
\hline
\end{tabular}

Sumber: Hasil Olahan Data Primer, 2020.

Data pada Tabel 5 menunjukkan bahwa indikator yang dominan dalam membentuk variabel kepuasan pasien RJTL di RSU St Madyang Palopo adalah indikator sikap profesional petugas RS dengan nilai rata-rata 4,72, dan kemudian diikuti indikator senang dengan pelayanan dari petugas RS dengan nilai rata-rata 4,57. Sedangkan indikator pelayanan diberikan sesuai dengan harapan pasien JKN-KIS dengan nilai rata-rata 4,38 memberikan proporsi terkecil dalam membentuk variabel kepuasan Pasien RJTL RSU St. Madyang. Kecenderungan dari data menunjukkan bahwa kepuasan Pasien RJTL RSU St. Madyang di Kota Palopo masih tergolong baik, namun masih perlu ditingkatkan terutama pada indikator yang memberikan proporsi terkecil agar kepuasan Pasien RJTL RSU St. Madyang dapat ditingkatkan di masa akan datang.

\section{Tampilan fisik $\left(X_{1}\right)$}

Tampilan fisik adalah mutu pelayanan dari RSU St Madyang Palopo yang dapat berupa wujud/tampilan fisik dan sesuai kenyataan yang dialami dan dirasakan oleh Pasien RJTL RSU St. Madyang. Indikator yang digunakan adalah: 1) Ruang tunggu bersih, rapi, dan nyaman; 2) Penampilan petugas RS yang menarik; dan 3) Terdapat tanda-tanda anjuran seperti: harap tenang, dan dilarang merokok. Adapun distribusi frekuensi tanggapan responden tentang variabel tampilan fisik dapat dilihat pada tabel berikut ini.

Tabel 6. Deskripsi Variabel Tampilan fisik $\left(\mathrm{X}_{\mathbf{1}}\right)$

\begin{tabular}{|l|c|c|c|c|c|c|}
\hline \multirow{2}{*}{ Indikator } & \multicolumn{5}{|c|}{ Frekuensi Jawaban (orang)/(\%) } & \multirow{2}{*}{ Mean } \\
\cline { 2 - 6 } & STS & TS & CS & S & SS & \\
\hline Ruang tunggu bersih, rapi, dan nyaman & 0 & 0 & 7 & 31 & 61 & 4,55 \\
\hline Penampilan petugas RS yang menarik & 0 & 0 & 3 & 37 & 59 & 4,57 \\
\hline $\begin{array}{l}\text { Terdapat tanda-tanda anjuran seperti: harap } \\
\text { tenang, dan dilarang merokok }\end{array}$ & 0 & 0 & 9 & 38 & 52 & \multirow{2}{*}{4,43} \\
\hline
\end{tabular}

Sumber: Hasil Olahan Data Primer, 2020.

Data pada Tabel 6 menunjukkan bahwa indikator yang dominan dalam membentuk variabel tampilan fisik adalah indikator penampilan Petugas RS yang menarik dengan nilai rata-rata 4,57, dan kemudian diikuti indikator ruang tunggu bersih, rapi, dan nyaman dengan nilai rata-rata 4,55. Sedangkan indikator terdapat tanda-tanda anjuran seperti: harap tenang, dan dilarang merokok dengan nilai rata-rata 4,43 memberikan proporsi terkecil dalam membentuk variabel tampilan fisik. Kecenderungan dari data menunjukkan bahwa tampilan fisik tergolong baik, namun masih perlu ditingkatkan terutama pada indikator yang membentuknya agar dapat meningkatkan kepuasan Pasien RJTL RSU St. Madyang di masa akan datang.

\section{Kehandalan $\left(\mathrm{X}_{2}\right)$}

Kehandalan adalah kemampuan untuk memberikan pelayanan administrasi yang optimal dan akurat kepada Pasien RJTL RSU St. Madyang. Indikator yang digunakan dalam penelitian ini adalah: 1) Kecepatan pelayanan administrasi; 2) Ketepatan pelayanan administrasi; dan 3) Kelancaran pelayanan administrasi. Adapun distribusi frekuensi tanggapan responden tentang variabel kehandalan dapat dilihat pada Tabel 7. 
Tabel 7. Deskripsi Variabel Kehandalan $\left(X_{2}\right)$

\begin{tabular}{|l|c|c|c|c|c|c|}
\hline \multirow{2}{*}{ Indikator } & \multicolumn{5}{|c|}{ Frekuensi Jawaban (orang)/(\%) } & \multirow{2}{*}{ Mean } \\
\cline { 2 - 6 } & STS & TS & CS & S & SS & \\
\hline Kecepatan pelayanan administrasi & 0 & 0 & 4 & 26 & 69 & 4,66 \\
\hline Ketepatan pelayanan administrasi & 0 & 0 & 8 & 29 & 62 & 4,55 \\
\hline Kelancaran pelayanan administrasi & 0 & 0 & 12 & 33 & 54 & 4,42 \\
\hline
\end{tabular}

Sumber: Hasil Olahan Data Primer, 2020.

Data pada Tabel 7 menunjukkan bahwa indikator yang dominan membentuk variabel kehandalan dalam kepuasan Pasien RJTL RSU St. Madyang di Kota Palopo adalah indikator kecepatan pelayanan administrasi dengan nilai rata-rata 4,66, dan kemudian diikuti indikator ketepatan pelayanan administrasi dengan nilai rata-rata 4,55. Sedangkan indikator kelancaran pelayanan administrasi dengan nilai rata-rata 4,42 memberikan proporsi terkecil dalam membentuk variabel kehandalan. Kecenderungan dari data menunjukkan bahwa variabel kehandalan tergolong baik, namun masih perlu ditingkatkan terutama pada indikator yang memberikan proporsi terendah agar dapat meningkatkan kepuasan Pasien RJTL RSU St. Madyang di masa akan datang.

\section{Ketanggapan $\left(X_{3}\right)$}

Ketanggapan adalah kemauan pihak pemberi pelayanan administrasi untuk memberikan informasi dan membantu merespon kebutuhan atau keinginan Pasien RJTL RSU St. Madyang dengan segera. Indikator yang digunakan dalam penelitian ini adalah: 1) Kecepatan mengatasi keluhan Pasien RJTL RSU St. Madyang; 2) Menjelaskan prosedur yang tidak dipahami Pasien RJTL RSU St. Madyang; dan 3) Penyampaian informasi dengan jelas. Adapun distribusi frekuensi tanggapan responden tentang variabel ketanggapan dapat dilihat pada Tabel 7.

Tabel 8. Deskripsi Variabel Ketanggapan $\left(X_{3}\right)$

\begin{tabular}{|l|c|c|c|c|c|c|}
\hline \multirow{2}{*}{ Indikator } & \multicolumn{5}{|c|}{ Frekuensi Jawaban (orang)/(\%) } & \multirow{2}{*}{ Mean } \\
\cline { 2 - 6 } $\begin{array}{l}\text { Kecepatan mengatasi keluhan Pasien RJTL } \\
\text { RSU St. Madyang }\end{array}$ & 0 & 0 & 4 & 23 & 72 & 4,69 \\
\hline $\begin{array}{l}\text { Menjelaskan prosedur yang tidak dipahami } \\
\text { Pasien RJTL RSU St. Madyang }\end{array}$ & 0 & 0 & 4 & 35 & 60 & 4,57 \\
\hline Penyampaian informasi dengan jelas & 0 & 0 & 13 & 35 & 51 & 4,38 \\
\hline
\end{tabular}

Sumber: Hasil Olahan Data Primer, 2020.

Data pada Tabel 8 menunjukkan bahwa indikator yang dominan dalam membentuk variabel ketanggapan dalam kepuasan Pasien RJTL RSU St. Madyang di Kota Palopo adalah indikator kecepatan mengatasi keluhan Pasien RJTL RSU St. Madyang dengan nilai rata-rata 4,69, dan kemudian diikuti indikator menjelaskan prosedur yang tidak dipahami Pasien RJTL RSU St. Madyang dengan nilai ratarata 4,57 , dan indikator penyampaian informasi dengan jelas dengan nilai rata-rata 4,38 memberikan proporsi terkecil dalam membentuk variabel ketanggapan. Kecenderungan dari data menunjukkan bahwa variabel ketanggapan perlu ditingkatkan terutama indikator yang membentuknya agar dapat meningkatkan kepuasan Pasien RJTL RSU St. Madyang di masa akan datang.

\section{Jaminan $\left(X_{4}\right)$}

Jaminan adalah kepastian pemberi pelayanan administrasi yang dapat mengatasi keluhan Pasien RJTL RSU St. Madyang. Indikator yang digunakan adalah: 1) jaminan keamanan pelayanan administrasi; 2) adanya tanggungjawab Petugas RS; dan 3) memahami kebutuhan para Pasien RJTL RSU St. Madyang. Adapun distribusi frekuensi tanggapan responden tentang variabel jaminan dapat dilihat pada Tabel 9.

Tabel 9. Deskripsi Variabel Jaminan (X4)

\begin{tabular}{|l|c|c|c|c|c|c|}
\hline \multirow{2}{*}{ Indikator } & \multicolumn{5}{|c|}{ Frekuensi Jawaban (orang)/(\%) } & \multirow{2}{*}{ Mean } \\
\cline { 2 - 7 } & STS & TS & CS & S & SS & \multirow{2}{*}{$\begin{array}{l}\text { Jaminan keamanan pelayanan } \\
\text { administrasi }\end{array}$} \\
\hline Adanya tanggungjawab Petugas RS & 0 & 0 & 0 & 17 & 83 & 4,87 \\
\hline
\end{tabular}




\begin{tabular}{|l|l|l|l|l|l|l|}
\hline $\begin{array}{l}\text { Memahami kebutuhan para Pasien RJTL } \\
\text { RSU St. Madyang }\end{array}$ & 0 & 0 & 4 & 23 & 72 & 4,69 \\
\hline
\end{tabular}

Sumber: Hasil Olahan Data Primer, 2020.

Data pada Tabel 9 menunjukkan bahwa indikator yang dominan dalam membentuk variabel jaminan terhadap kepuasan Pasien RJTL RSU St. Madyang di Kota Palopo adalah indikator jaminan keamanan pelayanan administrasi dengan nilai rata-rata 4,87, dan adanya tanggungjawab Petugas RS dengan nilai rata-rata 4,73. Sedangkan indikator memahami kebutuhan para Pasien RJTL RSU St. Madyang dengan nilai rata-rata 4,69 memberikan proporsi terkecil dalam membentuk variabel jaminan. Kecenderungan dari data menunjukkan bahwa variabel jaminan tergolong baik, namun masih perlu ditingkatkan terutama pada indikator yang membentuknya agar dapat meningkatkan kepuasan Pasien RJTL RSU St. Madyang di masa akan datang.

\section{Empati $\left(X_{5}\right)$}

Empati adalah pemberian perhatian yang sungguh-sungguh dari petugas pelayanan administrasi kepada Pasien RJTL RSU St. Madyang. Indikator yang digunakan dalam penelitian ini adalah: 1) Ramah kepada Pasien RJTL RSU St. Madyang; 2) Sopan dalam bertutur kata dengan Pasien RJTL RSU St. Madyang; dan 3) Memberikan pelayanan yang adil kepada Pasien RJTL RSU St. Madyang. Adapun distribusi frekuensi tanggapan responden tentang variabel empati dapat dilihat pada Tabel 10.

Tabel 10. Deskripsi Variabel Empati $\left(X_{5}\right)$

\begin{tabular}{|l|c|c|c|c|c|c|}
\hline \multicolumn{2}{|c|}{ Indikator } & \multicolumn{2}{|c|}{ Frekuensi Jawaban (orang)/(\%) } & \multirow{2}{*}{ Mean } \\
\cline { 2 - 6 } & STS & TS & CS & S & SS & \\
\hline Ramah kepada Pasien RJTL RSU St. Madyang & 0 & 0 & 1 & 28 & 70 & 4,70 \\
\hline $\begin{array}{l}\text { Sopan dalam bertutur kata dengan Pasien RJTL RSU St. } \\
\text { Madyang }\end{array}$ & 0 & 0 & 1 & 20 & 78 & 4,78 \\
\hline $\begin{array}{l}\text { Memberikan pelayanan yang adil kepada Pasien RJTL RSU } \\
\text { St. Madyang }\end{array}$ & 0 & 0 & 1 & 32 & 66 & 4,66 \\
\hline
\end{tabular}

Sumber: Hasil Olahan Data Primer, 2020.

Data pada Tabel 10 menunjukkan bahwa indikator yang dominan dalam membentuk variabel empati terhadap kepuasan Pasien RJTL RSU St. Madyang di Kota Palopo adalah indikator sopan dalam bertutur kata dengan Pasien RJTL RSU St. Madyang dengan nilai rata-rata 4,78, dan kemudian diikuti indikator ramah kepada Pasien RJTL RSU St. Madyang dengan nilai rata-rata 4,70. Sedangkan indikator memberikan pelayanan yang adil kepada Pasien RJTL RSU St. Madyang dengan nilai rata-rata 4,66 memberikan proporsi terkecil dalam membentuk variabel empati. Kecenderungan dari data menunjukkan bahwa variabel empati masih perlu ditingkatkan agar dapat menunjang kepuasan Pasien RJTL RSU St. Madyang di masa akan datang.

\section{c) Pengujian Instrumen Penelitian}

\section{Uji Validitas}

Uji validitas dilakukan dengan mengkorelasikan skor tiap item dengan skor total dari masingmasing atribut. Uji validitas digunakan untuk melihat ketepatan dan kecermatan dari sebuah instrumen penelitian dalam fungsi ukurnya mengukur item-item pernyataan yang dibuat. Instrumen yang valid mempunyai arti bahwa alat ukur yang digunakan dalam bentuk pernyataan untuk memperoleh data (mengukur) juga dinyatakan valid. Item pernyataan yang memiliki korelasi positif tinggi dapat dianggap memiliki validitas yang tinggi pula. Menurut Sugiyono (2007:233), corrected item total corelation merupakan korelasi antar skor total item, sehingga interpretasinya dengan mengkonsultasikan nilai kritis r-tabel, jika r hitung > nilai kritis r-tabel product moment maka instrument dinyatakan valid atau dapat dikatakan bahwa item pernyataan dari cerminan setiap variabel dalam penelitian ini keberadaannya pada instrumen penelitian dinyatakan valid (sahih). Adapun hasil uji validitas dari setiap item pernyataan variabel dalam penelitian ini, dapat dilihat pada Tabel 11. 
Tabel 10. Hasil Uji Validitas Instrumen Penelitian

\begin{tabular}{|l|c|c|c|c|}
\hline \multirow{4}{*}{ Variabel } & Item & $\begin{array}{c}\text { Corrected Item- } \\
\text { Total Correlation } \\
\text { (r-hitung) }\end{array}$ & $\begin{array}{c}\text { r-Product Moment } \\
(\mathrm{n}=99 ; \mathrm{a} 0,01) \\
(\mathrm{r} \text { - tabel })\end{array}$ & Keterangan \\
\hline \multirow{3}{*}{$\begin{array}{l}\text { Kepuasan Pasien RJTL RSU } \\
\text { St. Madyang }(\mathrm{Y})\end{array}$} & 1 & 0,848 & 0,195 & Valid \\
\cline { 2 - 5 } & 2 & 0,852 & 0,195 & Valid \\
\cline { 2 - 5 } & 3 & 0,630 & 0,195 & Valid \\
\hline Tampilan fisik $\left(\mathrm{X}_{1}\right)$ & 1 & 0,753 & 0,195 & Valid \\
\cline { 2 - 5 } & 2 & 0,770 & 0,195 & Valid \\
\hline Kehandalan $\left(\mathrm{X}_{2}\right)$ & 1 & 0,728 & 0,195 & Valid \\
\cline { 2 - 5 } & 2 & 0,808 & 0,195 & Valid \\
\cline { 2 - 5 } & 3 & 0,781 & 0,195 & Valid \\
\hline Ketanggapan $\left(\mathrm{X}_{3}\right)$ & 1 & 0,746 & 0,195 & Valid \\
\cline { 2 - 5 } & 2 & 0,769 & 0,195 & Valid \\
\hline Jaminan $\left(\mathrm{X}_{4}\right)$ & 3 & 0,852 & 0,195 & Valid \\
\cline { 2 - 5 } & 2 & 0,699 & 0,195 & Valid \\
\cline { 2 - 5 } & 3 & 0,668 & 0,195 & Valid \\
\hline Empati $\left(\mathrm{X}_{5}\right)$ & 1 & 0,666 & 0,195 & Valid \\
\cline { 2 - 5 } & 2 & 0,665 & 0,195 & Valid \\
\cline { 2 - 5 }
\end{tabular}

Sumber: Hasil Analisis, 2020.

Berdasarkan hasil uji validitas yang terlihat pada Tabel 10, diperoleh nilai corrected item total corelation ( $\mathrm{r}$ hitung) dari 18 butir pernyataan berada antara 0,630 sampai 0,852 , dimana nilai $r$ hitung lebih besar dari nilai $\mathrm{r}$ tabel, untuk $\mathrm{n}=99$ pada taraf a 0,01 diperoleh $\mathrm{r}$ tabel $=0,195$. Dengan demikian, dapat dikatakan bahwa semua butir pernyataan pada kuisioner adalah valid atau mampu mengungkapkan sesuatu yang akan diukur oleh kuesioner tersebut, sehingga dapat digunakan untuk analisis selanjutnya. Hasil uji validitas dari ketiga butir pernyataan variabel kepuasan Pasien RJTL RSU St. Madyang di Kota Palopo diperoleh nilai Corrected Item Total Correlation ( $\mathrm{r}$ hitung) antara 0,630 0,852 atau $r$ hitung $>r$ tabel 0,195. Hal ini berarti setiap butir pernyataan dari variabel kepuasan Pasien RJTL RSU St. Madyang yang digunakan dalam penelitian ini adalah valid (sahih). Hasil uji validitas dari ketiga butir pernyataan variabel tampilan fisik diperoleh nilai Corrected Item Total Correlation ( $\mathrm{r}$ hitung) antara $0,728-0,770$ atau $r$ hitung $>r$ tabel 0,195. Hal ini berarti setiap butir pernyataan dari variabel tampilan fisik yang digunakan dalam penelitian ini adalah valid (sahih). Hasil uji validitas dari ketiga butir pernyataan variabel kehandalan diperoleh nilai Corrected Item Total Correlation ( $\mathrm{r}$ hitung) antara 0,746-0,808 atau $r$ hitung $>r$ tabel 0,195 . Hal ini berarti setiap butir pernyataan dari variabel kehandalan yang digunakan dalam penelitian ini adalah valid (sahih). Hasil uji validitas dari keempat butir pernyataan variabel ketanggapan diperoleh nilai Corrected Item Total Correlation ( $\mathrm{r}$ hitung) antara $0,769-0,852$ atau $r$ hitung $>r$ tabel 0,195 . Hal ini berarti setiap butir pernyataan dari variabel ketanggapan yang digunakan dalam penelitian ini adalah valid (sahih). Hasil uji validitas ketiga butir pernyataan variabel jaminan diperoleh nilai Corrected Item Total Correlation ( $\mathrm{r}$ hitung) antara 0,659$0,666-0,699$ atau $r$ hitung $>r$ tabel 0,195. Hal ini berarti setiap butir pernyataan dari variabel jaminan yang digunakan dalam penelitian ini adalah valid (sahih). Hasil uji validitas dari keempat butir pernyataan variabel empati diperoleh nilai Corrected Item Total Correlation ( $\mathrm{r}$ hitung) antara 0,665 0,720 atau $r$ hitung $>r$ tabel 0,195 . Hal ini berarti setiap butir pernyataan dari variabel empati yang digunakan dalam penelitian ini adalah valid.

\section{Uji Reliabilitas}

Instrumen dalam penelitian ini dikatakan reliabel atau handal apabila dipergunakan beberapa kali untuk mengukur obyek yang sama sehingga menghasilkan data yang sama. Untuk melakukan uji reliabilitas terhadap instrumen penelitian adalah dengan menggunakan alpha cronbach yang mengelompokkan item-item menjadi dua atau beberapa belahan. Jika $\mathrm{r}$ hitung $>$ nilai kritis $\mathrm{r}$-tabel Product Moment maka data penelitian dianggap realiabel atau handal untuk digunakan sebagai input dalam proses penganalisisan data guna menguji hipotesis penelitian (Sugiyono, 2004). Adapun hasil uji 
reliabilitas dari setiap item pernyataan variabel yang digunakan dalam penelitian ini, dapat dilihat pada Tabel 12.

Tabel 12. Hasil Uji Reliabilitas Instrumen Penelitian

\begin{tabular}{|l|c|c|c|c|}
\hline \multirow{4}{*}{ Variabel } & Item & $\begin{array}{c}\text { Cronbach's Alpha } \\
\text { if Item Deleted } \\
\text { (r-hitung) }\end{array}$ & $\begin{array}{c}\text { r-Product Moment } \\
\text { (n=99; a 0,05 }) \\
(\mathrm{r} \text { - tabel) }\end{array}$ & Keterangan \\
\hline $\begin{array}{l}\text { Kepuasan Pasien RJTL RSU } \\
\text { St. Madyang }(\mathrm{Y})\end{array}$ & 1 & 0,957 & 0,195 & Reliabel \\
\cline { 2 - 5 } & 2 & 0,957 & 0,195 & Reliabel \\
\cline { 2 - 5 } & 3 & 0,961 & 0,195 & Reliabel \\
\hline Tampilan fisik $\left(\mathrm{X}_{1}\right)$ & 1 & 0,959 & 0,195 & Reliabel \\
\cline { 2 - 5 } & 2 & 0,959 & 0,195 & Reliabel \\
\hline Kehandalan $\left(\mathrm{X}_{2}\right)$ & 3 & 0,959 & 0,195 & Reliabel \\
\cline { 2 - 5 } & 2 & 0,958 & 0,195 & Reliabel \\
\cline { 2 - 5 } & 3 & 0,958 & 0,195 & Reliabel \\
\hline Ketanggapan $\left(\mathrm{X}_{3}\right)$ & 1 & 0,959 & 0,195 & Reliabel \\
\cline { 2 - 5 } & 2 & 0,959 & 0,195 & Reliabel \\
\cline { 2 - 5 } & 3 & 0,957 & 0,195 & Reliabel \\
\cline { 2 - 5 } & 1 & 0,960 & 0,195 & Reliabel \\
\cline { 2 - 5 } & 2 & 0,960 & 0,195 & Reliabel \\
\hline
\end{tabular}

Sumber: Hasil Analisis, 2020.

Data pada Tabel 12 menunjukkan hasil analisis uji reliabilitas, dimana nilai Cronbach's alpha (rhitung) dari 18 butir pernyataan berada antara 0,957 sampai 0,961, dimana nilai $\mathrm{r}$ hitung $>$ nilai $\mathrm{r}$ tabel 0,195 . Hal ini berarti setiap butir pernyataan dari variabel yang digunakan dalam penelitian ini adalah reliabel atau dapat dikatakan bahwa instrumen penelitian yang digunakan dalam fungsi ukurnya tidak menimbulkan arti ganda sehingga terjamin konsistensinya dalam mengukur pengaruh tampilan fisik, kehandalan, ketanggapan, jaminan, empati terhadap kepuasan Pasien RJTL RSU St. Madyang di Kota Palopo. Selanjutnya nilai Cronbach Alpha dari keseluruhan butir pernyataan dalam instrumen penelitian diperoleh sebesar 0,961, yang menunjukkan tingkat konsistensi (keandalan) dari instrumen penelitian yang digunakan adalah sebesar $96,1 \%$. Artinya apabila kuesioner dalam penelitian ini akan digunakan secara berulang-ulang pada populasi akan memberikan nilai objektifitas, stabilitas, akurasi dan konsistensi yang tinggi untuk mengukur pengaruh tampilan fisik, kehandalan, ketanggapan, jaminan, empati terhadap kepuasan Pasien RJTL RSU St. Madyang di Kota Palopo.

\section{d) Pengujian Hipotesis}

Berdasarkan hasil uji asumsi klasik yang meliputi: uji normalitas, uji multikolienaritas, dan uji heterokedastisitas menunjukkan bahwa regresi berganda yang diestimasi telah memenuhi syarat asumsi-asumsi klasik sehingga diharapkan hasilnya akan baik dalam menganalisis pengaruh tampilan fisik, kehandalan, ketanggapan, jaminan, empati terhadap kepuasan Pasien RJTL RSU St. Madyang di Kota Palopo. Pengujian terhadap hasil regresi yang diperoleh dilakukan pengujian secara simultan dengan menggunakan uji-F dan pengujian secara parsial dengan menggunakan uji-t. Untuk lebih jelasnya akan diuraikan berikut ini.

\section{Pengujian koefisien determinasi $\left(R^{2}\right)$}

Pengujian dengan koefisien determinasi $\left(\mathrm{R}^{2}\right)$ digunakan untuk mengetahui seberapa besar pengaruh dari seluruh variabel bebas terhadap variabel terikatnya. Perolehan nilai $\mathrm{R}^{2}$ dapat dilihat pada Tabel 13. 
Tabel 13. Hasil Pengujian Koefisien Determinasi $\left(\mathbf{R}^{2}\right)$

\begin{tabular}{|c|c|c|c|c|}
\hline \multicolumn{5}{|c|}{ Model Summaryb } \\
\hline Model & $\mathrm{R}$ & R Square & Adjusted R Square & Std. Error of the Estimate \\
\hline 1 & $.946^{\mathrm{a}}$ & .895 & .889 & .17366 \\
\hline \multicolumn{5}{|c|}{ a. Predictors: (Constant), X7, X4, X1, X5, X6, X2, X3 } \\
\hline \multicolumn{3}{|c|}{ b. Dependent Variable: Y } & & \\
\hline
\end{tabular}

Sumber: Hasil Analisis Data, 2020.

Berdasarkan hasil pengujian determinasi tersebut di atas, dapat dijelaskan bahwa besarnya koefisien determinasi $\left(R^{2}\right)$ adalah 0,895 . Angka koefisien determinasi ini menyatakan bahwa besarnya pengaruh variabel tampilan fisik, kehandalan, ketanggapan, jaminan, empati terhadap kepuasan Pasien RJTL RSU St. Madyang di Kota Palopo adalah sebesar 89,5\%, sedangkan sisanya sebesar 10,5\% dipengaruhi oleh variabel lain yang tidak diteliti dalam penelitian ini.

\section{Pengujian Hipotesis secara Simultan}

Pengujian secara simultan bertujuan melihat pengaruh secara bersama-sama variabel tampilan fisik, kehandalan, ketanggapan, jaminan, empati terhadap kepuasan Pasien RJTL RSU St. Madyang di Kota Palopo, dengan melihat nilai F-hitungnya. Adapun hasil pengujian secara serempak, dapat dilihat pada Tabel 14.

Tabel 14. Pengujian secara Simultan (Uji F)

\begin{tabular}{|c|c|c|c|c|c|c|}
\hline \multicolumn{7}{|c|}{ ANOVA $^{\mathbf{b}}$} \\
\hline \multicolumn{2}{|c|}{ Model } & Sum of Squares & df & Mean Square & $\mathrm{F}$ & Sig. \\
\hline \multirow[t]{3}{*}{1} & Regression & 23.855 & 5 & 4.771 & 157.834 & $.000^{\mathrm{a}}$ \\
\hline & Residual & 2.811 & 93 & .030 & & \\
\hline & Total & 26.667 & 98 & & & \\
\hline \multicolumn{5}{|c|}{ a. Predictors: (Constant), X5, X4, X1, X2, X3 } & & \\
\hline \multicolumn{3}{|c|}{ b. Dependent Variable: $\mathrm{Y}$} & & & & \\
\hline
\end{tabular}

Sumber: Hasil Analisis Data, 2020.

Data pada Tabel 13 menunjukkan bahwa nilai $\mathrm{F}$ hitung yang diperoleh adalah 157.834, sedangkan F tabel pada selang kepercayaan 95\% (df1=7; df2=99; $a=0,05)$ diperoleh nilai F-tabel 2,10). Dengan demikian, nilai $\mathrm{F}$ hitung $>\mathrm{F}$ tabel atau $157.834>2,10$, yang berarti variabel bebas berpengaruh signifikan terhadap variabel terikat $(\mathrm{Y})$. Nilai signifikansi (kolom sig.) diperoleh sig. $=000^{\mathrm{a}}$ lebih kecil dari tingkat alpha 0.05. Sejalan dengan hasil ini, maka dapat disimpulkan bahwa secara simultan atau bersamasama variabel tampilan fisik, kehandalan, ketanggapan, jaminan, empati berpengaruh signifikan dan positif terhadap kepuasan Pasien RJTL RSU St. Madyang di Kota Palopo. Dengan demikian, hipotesis pertama dari penelitian ini diterima (terbukti).

\section{Pengujian Hipotesis secara Parsial}

Pengujian hipotesis secara parsial digunakan untuk melihat pengaruh secara individu variabel tampilan fisik, kehandalan, ketanggapan, jaminan, empati terhadap kepuasan Pasien RJTL RSU St. Madyang di Kota Palopo. Hasil pengujiannya dapat dilihat melalui nilai t-hitungnya, sedangkan untuk melihat besarnya pengaruh digunakan angka beta atau standardized coefficient. Adapun hasil pengujian secara parsial (t-hitung) dapat dilihat pada Tabel 15. 
Tabel 14. Pengujian secara Parsial (Uji-t)

\begin{tabular}{|c|c|c|c|c|c|c|}
\hline \multirow{2}{*}{\multicolumn{2}{|c|}{ Model }} & \multicolumn{2}{|c|}{ Unstandardized Coefficients } & \multirow{2}{*}{$\begin{array}{c}\text { Standardized } \\
\text { Coefficients }\end{array}$} & \multirow[b]{2}{*}{$t$} & \multirow[b]{2}{*}{ Sig. } \\
\hline & & B & Std. Error & & & \\
\hline \multirow[t]{6}{*}{1} & (Constant) & .131 & .232 & & .565 & .573 \\
\hline & $\mathrm{X} 1$ & .047 & .060 & .048 & .777 & .439 \\
\hline & $\mathrm{X} 2$ & .171 & .068 & .182 & 2.510 & .014 \\
\hline & $\mathrm{X3}$ & .639 & .081 & .663 & 7.906 & .000 \\
\hline & $\mathrm{X} 4$ & .101 & .062 & .082 & 1.626 & .107 \\
\hline & $\mathrm{X} 5$ & .215 & .072 & .168 & 2.981 & .004 \\
\hline \multicolumn{2}{|c|}{ a. Dependent Variable: $Y$} & & & & & \\
\hline
\end{tabular}

Sumber: Data Diolah, 2020.

Berdasarkan pengujian secara parsial atau individu seperti pada Tabel 14 menunjukkan bahwa variabel kehandalan, ketanggapan, dan empati berpengaruh signifikan dan positif terhadap kepuasan Pasien RJTL RSU St. Madyang di Kota Palopo, sedangkan variabel tampilan fisik, dan jaminan berpengaruh tidak signifikan. Hal ini dapat diketahui dari nilai t-hitung yang diperoleh yakni t-hitung $>\mathrm{t}$-tabel, dan juga dapat diketahui melalui tingkat signifikansinya yakni nilai sig. $(\mathrm{P})<0,05$, dimana pada kolom sig./probabilitas pada tabel di atas yaitu tampilan fisik $(\mathrm{P}=0,439>0,05)$ atau tidak signifikan, kehandalan $(P=0,014<0,05)$ atau signifikan, ketanggapan $(P=0,000<0,05)$ atau signifikan, jaminan $(P=0,107>0,05)$ atau tidak signifikan, dan empati $(P=0,004<0,05)$ atau signifikan. Selanjutnya pada tabel di atas, dapat pula diketahui hasil persamaan regresi linier berganda dari model penelitian ini adalah sebagai berikut:

$$
Y=0,131+0,047 X_{1}+0,171 X_{2}+0,639 X_{3}+0,101 X_{4}+0,215 X_{5}
$$

Berdasarkan persamaan regresi linier berganda tersebut di atas, maka dapat diinterprestasi sebagai berikut:

a. Konstanta $\left(b_{0}\right)$ diperoleh nilai 0,131 menyatakan jika tidak dilakukan upaya peningkatan kualitas pelayanan adminitrasi terkait tampilan fisik, kehandalan, ketanggapan, jaminan, empati, maka kepuasan Pasien RJTL RSU St. Madyang di Kota Palopo adalah konstan yang jika diangkakan sebesar 0,131.

b. $b_{1}=0,047$, yang menunjukkan bahwa variabel tampilan fisik berpengaruh tidak signifikan terhadap kepuasan Pasien RJTL RSU St. Madyang di Kota Palopo. Hal ini berarti tampilan fisik belum mampu meningkatkan kepuasan Pasien RJTL RSU St. Madyang secara signifikan. Besarnya pengaruh variabel tampilan fisik terhadap kepuasan Pasien RJTL RSU St. Madyang di Kota Palopo dapat diketahui melalui angka beta atau standardized coefficient yaitu 0,048.

c. $b_{2}=0,171$, yang menunjukkan bahwa variabel kehandalan berpengaruh positif dan signifikan terhadap kepuasan Pasien RJTL RSU St. Madyang di Kota Palopo. Hal ini berarti semakin memadai kehandalan, maka kepuasan Pasien RJTL RSU St. Madyang juga akan cenderung meningkat. Besarnya pengaruh variabel kehandalan terhadap kepuasan Pasien RJTL RSU St. Madyang dapat diketahui melalui angka beta atau standardized coefficient yaitu 0,182.

d. $. b_{3}=0,639$, yang menunjukkan bahwa variabel ketanggapan berpengaruh signifikan terhadap kepuasan Pasien RJTL RSU St. Madyang di Kota Palopo. Hal ini berarti semakin meningkat kegiatan ketanggapan, maka kepuasan Pasien RJTL RSU St. Madyang juga akan cenderung meningkat. Besarnya pengaruh variabel ketanggapan terhadap kepuasan Pasien RJTL RSU St. Madyang di Kota Palopo dapat diketahui melalui angka beta atau standardized coefficient yaitu 0,663 .

e. $b_{4}=0,101$, yang menunjukkan bahwa variabel jaminan berpengaruh positif dan signifikan terhadap kepuasan Pasien RJTL RSU St. Madyang di Kota Palopo. Hal ini berarti jaminan belum mampu meningkatkan kepuasan Pasien RJTL RSU St. Madyang secara signifikan. Besarnya 
pengaruh variabel jaminan terhadap kepuasan Pasien RJTL RSU St. Madyang di Kota Palopo dapat diketahui melalui angka beta atau standardized coefficient yaitu 0,082.

f. $\quad b_{5}=0,072$, yang menunjukkan bahwa variabel empati berpengaruh signifikan terhadap kepuasan Pasien RJTL RSU St. Madyang di Kota Palopo. Hal ini berarti semakin meningkat kegiatan ketanggapan, maka kepuasan Pasien RJTL RSU St. Madyang juga akan cenderung meningkat. Besarnya pengaruh variabel empati terhadap kepuasan Pasien RJTL RSU St. Madyang di Kota Palopo dapat diketahui melalui angka beta atau standardized coefficient yaitu 0,168.

Berdasarkan uraian di atas dapat diketahui bahwa variabel kehandalan, ketanggapan, dan empati secara individu berpengaruh signifikan dan positif terhadap kepuasan Pasien RJTL RSU St. Madyang di Kota Palopo. Sedangkan variabel tampilan fisik dan jaminan berpengaruh tidak signifikan. Selanjutnya dari kelima variabel bebas yang signifikan, ternyata variabel ketanggapan yang berpengaruh dominan dalam meningkatkan kepuasan Pasien RJTL RSU St. Madyang di Kota Palopo, karena diperoleh nilai standardized beta coefficients yang lebih besar dari variabel lainnya.

\section{e) Pengujian Asumsi Klasik}

\section{Uji Normalitas}

Sebelum melakukan analisis regresi berganda, maka terlebih dahulu melakukan uji normalitas untuk melihat apakah model regresi yang digunakan memiliki residual yang terdistribusi secara normal atau tidak. Apabila didapatkan residual yang tidak tersebar secara normal pada suatu regresi, maka akan menghasilkan regresi yang tidak baik atau tidak konsisten dan efisien. Adapun hasil pengujian grafis normalitas dalam penelitian ini dapat dilihat pada Gambar 3.

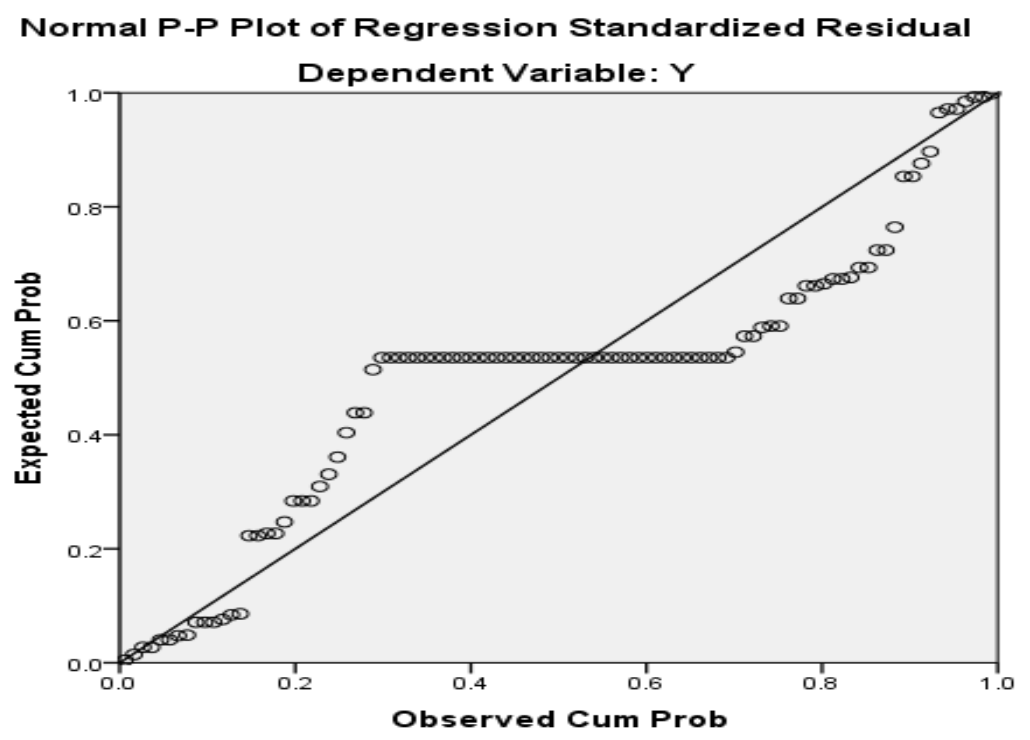

Gambar 2. Hasil Uji Normalitas

Gambar 3 menunjukkan bahwa sebaran titik berada sepanjang garis diagonal dan mengikuti arus garis diagonal. Pengujian distribusi data yang dilakukan dengan metode grafis ini menunjukkan hasil yang dapat disimpulkan bahwa model regresi layak digunakan untuk mengukur pengaruh tampilan fisik, kehandalan, ketanggapan, jaminan, empati terhadap kepuasan Pasien RJTL RSU St. Madyang di Kota Palopo, karena telah memenuhi asumsi normalitas.

\section{Uji Multikolinearitas}

Keberadaan multikolinearitas dalam suatu regresi akan mengganggu hasil regresi penelitian, sehingga tidak menghasilkan parameter yang efisien dan efektif yang akan membuat kesalahan dalam parameter yang dihasilkan. Regresi dikatakan baik jika suatu regresi tidak memiliki multikolinearitas di dalamnya sehingga tidak ada gangguan yang diharapkan akan terjadi pada regresi tersebut. Keberadaan multikolinearitas dapat dilihat melalui nilai VIF (Variance Inflation Factors) atau nilai toleransinya, yakni apabila nilai VIF > 10 atau secara kebalikannya dengan melihat nilai toleransinya < 
0,1. Adapun hasil perhitungan nilai VIF atau toleransi yang dilakukan untuk regresi dalam penelitian ini dapat dilihat pada Tabel 15.

Tabel 15. Hasil Uji Multikolinearitas

\begin{tabular}{|l|l|c|c|}
\hline \multirow{2}{*}{ Model } & \multicolumn{2}{|c|}{ Collinearity Statistics } \\
\cline { 2 - 4 } 1 & (Constant) & Tolerance & VIF \\
\cline { 2 - 4 } & X1 & & 3,355 \\
\cline { 2 - 4 } & X2 & 0,298 & 4,621 \\
\cline { 2 - 4 } & X3 & 0,216 & 6,210 \\
\cline { 2 - 4 } & X4 & 0,161 & 2,224 \\
\cline { 2 - 4 } & X5 & 0,450 & 2,788 \\
\hline
\end{tabular}

Sumber: Hasil Penelitian, 2020.

Hasil uji multikolinearitas pada Tabel 12 menunjukkan bahwa semua variabel memiliki nilai VIF yang lebih kecil dari 10 dan nilai toleransi yang lebih besar dari 0,1. Ini menunjukkan bahwa indikasi keberadaan multikolinearitas pada persamaan yang dilakukan tidak terbukti atau tidak terdapat multikolinearitas dalam persamaan yang dilakukan atau hubungan yang terjadi antar variabel bebas (tampilan fisik, kehandalan, ketanggapan, jaminan, empati) dapat ditoleransi sehingga tidak akan mengganggu hasil regresi.

\section{Uji Heterokedastisitas}

Uji heterokedastisitas dalam penelitian ini dimaksudkan untuk melihat apakah pengambilan sampel dilakukan dengan benar pada populasi yang tepat atau dengan perkataan lain apakah terjadi ketidaksamaan varians dari residual regresi. Suatu model regresi yang mengandung heterokedastisitas akan menghasilkan parameter yang bias yang akan menyebabkan kesalahan dalam perlakuan. Suatu model regresi yang baik apabila di dalamnya tidak diperoleh heterokedastisitas melainkan homokedastisitas. Uji heterokedastisitas dapat diketahui dengan melihat plot grafik atau hubungan antara variabel terikat dengan nilai residualnya. Heterokedastisitas akan muncul apabila terdapat pola tertentu antar keduanya seperti bergelombang dan kontinyu atau menyempit atau melebar teratur, sedangkan homokedastisitas akan muncul apabila tidak diperoleh pola yang jelas atau titik-titik yang diperoleh menyebar di atas dan di bawah angka 0 pada sumbu Y. Berdasarkan Gambar 4 dapat dijelaskan bahwa titik-titik tersebut menyebar di atas dan di bawah garis nol secara acak. Hal ini berarti model regresi yang digunakan dalam penelitian ini tidak menunjukkan adanya heterokedastisitas, melainkan homokedastisitas yang tidak menghasilkan parameter bias yang menyebabkan kesalahan dalam perlakuan. Untuk lebih jelasnya dapat dilihat pada Gambar 3. 


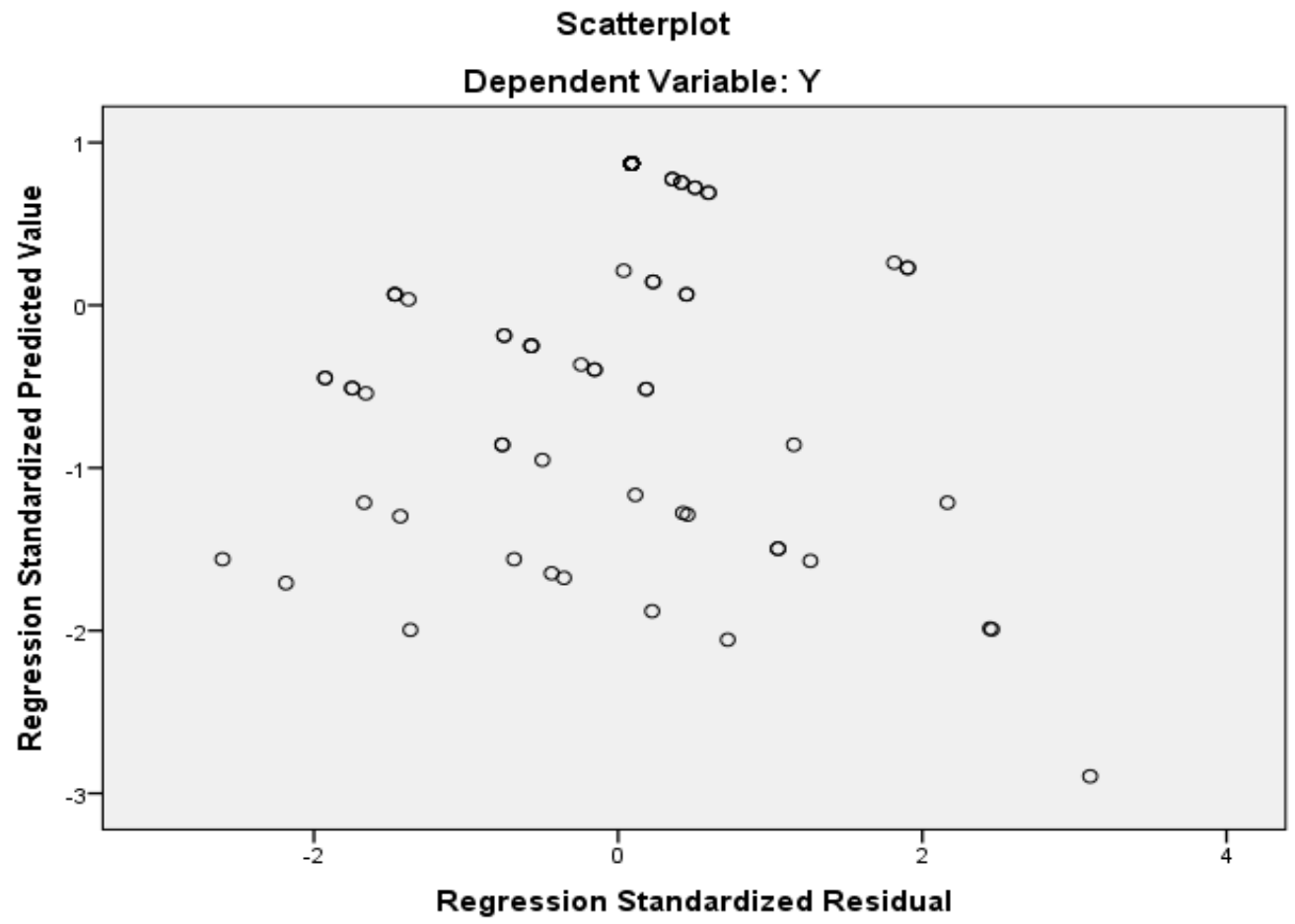

Gambar 3. Hasil Uji Heterokedastisitas

\section{Pembahasan}

Hasil pengujian secara simultan menunjukkan variabel tampilan fisik, kehandalan, ketanggapan, jaminan, dan empati secara simultan berpengaruh signifikan terhadap kepuasan Pasien RJTL RSU St. Madyang di Kota Palopo. Selanjutnya hasil pengujian secara parsial menunjukkan bahwa variabel kehandalan, ketanggapan, dan empati secara individu berpengaruh signifikan dan positif terhadap kepuasan Pasien RJTL RSU St. Madyang di Kota Palopo, sedangkan variabel tampilan fisik dan jaminan berpengaruh tidak signifikan. Adapun pembahasan mengenai pengaruh variabel tampilan fisik, kehandalan, ketanggapan, jaminan, empati terhadap kepuasan Pasien RJTL RSU St. Madyang di Kota Palopo, akan diuraikan sebagai berikut:

\section{Pengaruh tampilan fisik terhadap kepuasan Pasien RJTL RSU St. Madyang}

Tampilan fisik adalah mutu pelayanan dari BPJS Cabang Palopo yang dapat berupa wujud/tampilan fisik dan sesuai kenyataan yang dialami dan dirasakan oleh Pasien RJTL RSU St. Madyang. Hasil pengujian secara parsial atau uji-t menunjukkan bahwa variabel tampilan fisik berpengaruh tidak signifikan dan positif terhadap kepuasan Pasien RJTL RSU St. Madyang di Kota Palopo. Pengaruh positif mengindikasikan ada hubungan yang searah antara tampilan fisik dengan kepuasan Pasien RJTL RSU St. Madyang di Kota Palopo, artinya jika tersedia tampilan fisik dengan layanan yang baik, maka kepuasan Pasien RJTL RSU St. Madyang juga akan meningkat. Variabel tampilan fisik memberikan pengaruh tidak signifikan terhadap kepuasan Pasien RJTL RSU St. Madyang, hal ini berarti tampilan fisik belum mampu meningkatkan kepuasan Pasien RJTL RSU St. Madyang di Kota Palopo. Oleh karena itu, semua indikator dari variabel tampilan fisik dan empati perlu diberdayakan secara maksimal agar dapat meningkatkan kepuasan Pasien RJTL RSU St. Madyang di Kota Palopo. Adanya pengaruh tidak signifikan variabel tampilan fisik terhadap kepuasan Pasien RJTL RSU St. Madyang di Kota Palopo sangat ditentukan oleh peran indikator yang membentuknya yang masih perlu diberdayakan secara maksimal, termasuk ruang tunggu harus setiap hari dibersihkan, rapi, dan nyaman serta tidak berdebu; penampilan Petugas RS yang menarik dan sopan; setiap ruangan terdapat tanda-tanda anjuran seperti: harap tenang, dilarang merokok dan buang sampah, jaga jarak, dan lain-lain. Ketiga indikator tersebut harus dapat diberdayakan secara maksimal agar memberikan kontribusi yang besar dalam membentuk variabel tampilan fisik sehingga dapat memberikan pengaruh yang signifikan terhdap kepuasan JKN-KIS di Kota Palopo di masa akan datang. 
Indikator yang dominan dalam membentuk variabel tampilan fisik adalah indikator penampilan Petugas RS yang menarik, dan kemudian diikuti indikator ruang tunggu bersih, rapi, dan nyaman. Sedangkan indikator terdapat tanda-tanda anjuran seperti: harap tenang, dan dilarang merokok memberikan proporsi terkecil dalam membentuk variabel tampilan fisik, sehingga indikator tersebut perlu ditingkatkan agar dapat memberikan konstribusi yang besar dalam membentuk variabel tampilan fisik. Dengan memberdayakan secara maksimal dari ketiga indikator tersebut, diharapkan dapat memberikan pengaruh signifikan terhadap peningkatan kepuasan Pasien RJTL RSU St. Madyang di Kota Palopo. Penelitian ini didukung oleh teori Parasuraman (2001:32), bahwa bukti fisik dalam kualitas pelayanan adalah aktualisasi nyata secara fisik dapat terlihat atau digunakan oleh pegawai sesuai penggunaan dan pemanfaatannya yang dapat dirasakan membantu pelayanan, sehingga puas atas pelayanan yang dirasakan, sekaligus menunjukkan kepuasan atas pemberian pelayanan yang diberikan. Selanjutnya menurut Martul (2014:49), kualitas pelayanan berupa kondisi fisik merupakan bentuk kualitas pelayanan nyata yang memberikan adanya apresiasi membentuk tanggapan positif bagi setiap individu yang dilayani dan menjadi suatu penilaian dalam menentukan kemampuan yang dapat dilihat secara fisik, baik dalam menggunakan alat dan perlengkapan pelayanan, kemampuan menginovasi dan mengadopsi teknologi, dan menunjukkan suatu perfomance tampilan yang cakap, berwibawa dan memiliki integritas yang tinggi sebagai wujud dari kepuasan yang ditunjukkan kepada orang yang mendapatkan pelayanan.

Hasil penelitian ini membuktikan bahwa variabel tampilan fisik berpengaruh tidak signifikan terhadap kepuasan Pasien RJTL RSU St. Madyang di Kota Palopo. Hal ini berarti variabel tampilan fisik belum mampu meningkatkan kepuasan Pasien RJTL RSU St. Madyang secara signifikan di Kota Palopo. Oleh karena itu tampilan fisik perlu mendapatkan perhatian khusus agar lebih diprioritaskan dengan memberdayakan setiap indikator-indikator yang membentuknya secara maksimal sehingga dapat memberikan pengaruh signifikan terhadap kepuasan Pasien RJTL RSU St. Madyang di Kota Palopo di masa akan datang. Hasil Penelitian ini sejalan dengan penelitian yang dilakukan oleh Junaedi (2012), bahwa tampilan fisik (tangibles) berpengaruh tidak signifikan terhadap kepuasan nasabah. Namun, penelitian ini tidak sejalan dengan penelitian yang dilakukan oleh Fatah (2015) dan Mariaty Silalahi (2017) membuktikan bahwa bukti fisik (tangibles) berpengaruh signifikan terhadap kepuasan pasien. Dengan demikian, penelitian ini dapat dijadikan acuan untuk penelitian lanjutan. Teori-teori tentang kualitas pelayanan ditinjau dari aspek tampilan fisik dan kepuasan pelayanan berlaku atau terbukti.

\section{Pengaruh kehandalan terhadap kepuasan Pasien RJTL RSU St. Madyang}

Kehandalan adalah kemampuan untuk memberikan pelayanan administrasi yang optimal dan akurat kepada Pasien RJTL RSU St. Madyang. Hasil pengujian secara parsial menunjukkan bahwa variabel kehandalan berpengaruh positif dan signifikan terhadap kepuasan Pasien RJTL RSU St. Madyang di Kota Palopo. Hal ini mengindikasikan ada hubungan yang searah antara kehandalan dengan kepuasan Pasien RJTL RSU St. Madyang di Kota Palopo, artinya semakin baik kehandalan maka kepuasan Pasien RJTL RSU St. Madyang juga akan cenderung meningkat. Variabel kehandalan memberikan pengaruh signifikan terhadap kepuasan Pasien RJTL RSU St. Madyang di Kota Palopo. Oleh karena itu, variabel kehandalan merupakan salah satu faktor yang dapat meningkatkan kepuasan Pasien RJTL RSU St. Madyang di Kota Palopo sehingga perlu terus ditingkatkan, namun indikator yang memberikan proporsi terendah masih terus ditingkatkan agar dapat meningkatkan kepuasan Pasien RJTL RSU St. Madyang di Kota Palopo. Adanya pengaruh signifikan variabel kehandalan terhadap kepuasan Pasien RJTL RSU St. Madyang di Kota Palopo sangat ditentukan oleh peran indikator yang membentuknya, yakni: kecepatan pelayanan administrasi; ketepatan pelayanan administrasi; dan kelancaran pelayanan administrasi. Ketiga indikator tersebut perlu diberdayakan secara maksimal agar memberikan kontribusi yang besar dalam membentuk variabel kehandalan guna mendukung peningkatan kepuasan JKN-KIS di Kota Palopo di masa akan datang.

Indikator yang dominan membentuk variabel kehandalan adalah indikator kecepatan pelayanan administrasi, artinya pelayanan administrasi sudah dilaksanakan dengan cepat. Kemudian diikuti indikator ketepatan pelayanan administrasi, artinya pelayanan administrasi sudah dilakukan dengan tepat. Sedangkan indikator kelancaran pelayanan administrasi memberikan proporsi terkecil dalam membentuk variabel kehandalan, sehingga indikator tersebut perlu ditingkatkan agar dapat memberikan konstribusi yang besar dalam membentuk variabel kehandalan. Dengan memberdayakan secara maksimal dari ketiga indikator tersebut, maka diharapkan dapat meningkatkan kepuasan Pasien 
RJTL RSU St. Madyang di Kota Palopo. Penelitian ini didukung oleh teori Parasuraman (2001:101), bahwa tuntutan kehandalan pegawai dalam memberikan pelayanan yang cepat, tepat mudah dan lancar menjadi syarat penilaian bagi orang yang dilayani dalam memperlihatkan aktualisasi kerja pegawai dalam memahami lingkup dan uraian kerja yang menjadi perhatian dan fokus dari setiap pegawai dalam memberikan pelayanannya. Inti pelayanan kehandalan adalah setiap pegawai memiliki kemapuan yang handal, mengetahui mengenai seluk prosedur kerja, mekanisme kerja, memperbaiki berbagai kekurangan atau penyimpangan yang tidak sesuai dengan prosedur kerja dan mampu menunjukkan, mengarahkan dan memberikan arahan yang benar kepada setiap bentuk pelayanan yang belum dimengerti oleh masyarakat, sehingga memberikan dampak positif atas pelayanan tersebut yaitu pegawai memahami, menguasai, handal, mandiri dan profesional atas uraian kerja yang ditekuninya.

Berdasarkan analisa tersebut, maka variabel kehandalan berpengaruh positif dan signifikan terhadap kepuasan Pasien RJTL RSU St. Madyang di Kota Palopo. Oleh karena itu, variabel kehandalan masih perlu ditingkatkan terutama pada indikator yang membentuknya agar kepuasan Pasien RJTL RSU St. Madyang di Kota Palopo dapat ditingkatkan di masa akan datang Hasil penelitian ini sejalan dengan penelitian yang dilakukan oleh Junaedi (2012) bahwa kehandalan berpengaruh signifikan terhadap kepuasan nasabah. Begitu pula hasil penelitian Fatah (2015) membuktikan bahwa kehandalan berpengaruh signifikan terhadap kepuasan pasien. Namun, penelitian ini tidak sejalan dengan penelitian yang dilakukan oleh Mariaty Silalahi (2017) yang membuktikan bahwa kehandalan berpengaruh tidak signifikan terhadap kepuasan pasien rawat inap. Dengan demikian, penelitian ini dapat dijadikan acuan untuk penelitian lanjutan. Teori-teori tentang kualitas pelayanan ditinjau dari aspek kehandalan dan kepuasan pelayanan berlaku atau terbukti.

\section{Pengaruh ketanggapan terhadap kepuasan Pasien RJTL RSU St. Madyang}

Ketanggapan adalah kemauan pihak pemberi pelayanan administrasi untuk memberikan informasi dan membantu merespon kebutuhan atau keinginan Pasien RJTL RSU St. Madyang dengan segera. Hasil pengujian secara parsial atau uji-t menunjukkan bahwa variabel ketanggapan berpengaruh signifikan terhadap kepuasan Pasien RJTL RSU St. Madyang di Kota Palopo. Hal ini berarti ketanggapan mampu meningkatkan kepuasan Pasien RJTL RSU St. Madyang di Kota Palopo secara signifikan. Adanya pengaruh signifikan dari ketanggapan sangat ditentukan oleh peran indikator yang membentuk variabel ketanggapan, yakni: Kecepatan mengatasi keluhan Pasien RJTL RSU St. Madyang; Menjelaskan prosedur yang tidak dipahami Pasien RJTL RSU St. Madyang; dan Penyampaian informasi dengan lebih jelas. Oleh karena itu, ketiga indikator dari variabel ketanggapan telah diberdayakan secara maksimal agar dapat meningkatkan secara signifikan kepuasan Pasien RJTL RSU St. Madyang di Kota Palopo. Indikator yang dominan membentuk variabel kehandalan adalah indikator kecepatan mengatasi keluhan Pasien RJTL RSU St. Madyang, artinya keluhan para Pasien RJTL RSU St. Madyang sudah dapat diatasi dengan cepat, kemudian diikuti indikator menjelaskan prosedur yang tidak dipahami Pasien RJTL RSU St. Madyang, artinya prosedur yang tidak dipahami Pasien RJTL RSU St. Madyang sudah dijelaskan secara rinci. Sedangkan pelayanan informasi lisan dan tertulis masih perlu penjelasan lebih rinci agar mampu mendukung variabel ketanggapan dalam meningkatkan kepuasan Pasien RJTL RSU St. Madyang di masa akan datang.

Penelitian ini didukung oleh teori Parasuraman (2001:63), pada prinsipnya inti dari bentuk pelayanan yang diterapkan dalam suatu instansi atau aktivitas pelayanan kerja yaitu memberikan pelayanan sesuai dengan tingkat ketanggapan atas permasalahan pelayanan yang diberikan. Kurangnya tanggapan tersebut dari orang yang menerima pelayanan, karena bentuk pelayanan tersebut baru dihadapi pertama kali, sehingga memerlukan banyak informasi mengenai syarat dan prosedur pelayanan yang cepat, mudah dan lancar, sehingga pihak pegawai atau pemberi pelayanan seyogyanya menuntun orang yang dilayani sesuai dengan penjelasan-penjelasan yang mendetail, singkat dan jelas yang tidak menimbulkan berbagai pertanyaan atau hal-hal yang menimbulkan keluh kesah dari orang yang mendapatkan pelayanan. Apabila hal ini dilakukan dengan baik, berarti pegawai tersebut memiliki kemampuan daya tanggap terhadap pelayanan yang diberikan dengan optimal sesuai tingkat kecepatan, kemudahan dan kelancaran dari suatu pelayanan yang ditangani oleh pegawai. Berdasarkan analisa tersebut, maka variabel ketanggapan menjadi faktor penting karena memberikan pengaruh dominan terhadap kepuasan Pasien RJTL RSU St. Madyang di Kota Palopo. Oleh karena itu, variabel ketanggapan perlu ditingkatkan terutama pada indikator yang memberikan 
proporsi terkecil dan perlu dipertahankan terutama pada indikator yang memberikan nilai terbesar dalam membentuk variabel ketanggapan sehingga diharapkan dapat mendukung peningkatan kepuasan Pasien RJTL RSU St. Madyang di Kota Palopo dapat ditingkatkan di masa akan datang.

Hasil penelitian ini sejalan dengan penelitian yang dilakukan oleh Mariaty Silalahi (2017) membuktikan daya tanggap berpengaruh signifikan terhadap kepuasan pasien. Begitu pula hasil penelitian Fatah (2015) juga membuktikan bahwa daya tanggap berpengaruh signifikan terhadap kepuasan pasien. Namun, penelitian ini tidak sejalan dengan penelitian Junaedi (2012) yang membuktikan bahwa variabel responsiveness (daya tanggap) berpengaruh tidak signifikan terhadap kepuasan nasabah. Dengan demikian, penelitian ini dapat dijadikan acuan untuk penelitian lanjutan. Teori-teori tentang kualitas pelayanan ditinjau dari aspek ketanggapan dan kepuasan pelayanan berlaku atau terbukti.

\section{Pengaruh jaminan terhadap kepuasan Pasien RJTL RSU St. Madyang}

Jaminan adalah kepastian pemberi pelayanan administrasi yang dapat mengatasi keluhan Pasien RJTL RSU St. Madyang. Hasil pengujian secara parsial menunjukkan bahwa variabel jaminan berpengaruh tidak signifikan terhadap kepuasan Pasien RJTL RSU St. Madyang di Kota Palopo. Hal ini mengindikasikan jaminan belum mampu meningkatkan kepuasan Pasien RJTL RSU St. Madyang di Kota Palopo, dalam arti pelayanan yang terkait dengan jaminan belum memberikan peningkatan kepuasan peserta secara signifikan. Oleh karena itu, pelayanan yang terkait dengan kebijakan jaminan perlu mendapat perhatian khusus untuk lebih ditingkatkan dengan memaksimalkan indikatorindikator yang membentuknya agar dapat meningkatkan kepuasan Pasien RJTL RSU St. Madyang di Kota Palopo. Pengaruh tidak signifikan variabel jaminan terhadap kepuasan Pasien RJTL RSU St. Madyang disebabkan karena belum maksimalnya sangat ditentukan oleh peran indikator yang membentuknya, termasuk jaminan keamanan pelayanan administrasi; adanya tanggungjawab Petugas RS; dan memahami kebutuhan para Pasien RJTL RSU St. Madyang. Indikator yang dominan dalam membentuk variabel jaminan adalah indikator jaminan keamanan pelayanan administrasi, artinya jaminan keamanan pelayanan administrasi belum terlaksana memadai. Begitu pula masih kurangnya tanggung jawab Petugas RS, dan juga belum memahami kebutuhan para Pasien RJTL RSU St. Madyang, sehingga ketiga indikator tersebut perlu diberdayakan secara maksimal agar kepuasan Pasien RJTL RSU St. Madyang di Kota Palopo dapat meningkat secara signifikan di masa akan datang.

Penelitian ini didukung oleh teori Barata (2013:201), jaminan atas pelayanan yang diberikan oleh pegawai sangat ditentukan oleh performance atau kinerja pelayanan, sehingga diyakini bahwa pegawai tersebut mampu memberikan pelayanan yang handal, mandiri dan profesional yang berdampak pada kepuasan pelayanan yang handal, mandiri dan profesional yang berdampak pada kepuasan pelayanan yang diterima. Selain dari performance tersebut, jaminan dari suatu pelayanan juga ditentukan dari adanya komitmen organisasi yang kuat, yang menganjurkan agar setiap pegawai memberikan pelayanan secara serius dan sungguh-sungguh untuk memuaskan orang yang dilayani. Bentuk jaminan yang lain yaitu jaminan terhadap pegawai yang memiliki perilaku kepribadian (personality behavior) yang baik dalam memberikan pelayanan, tentu akan berbeda pegawai yang memiliki watak atau karakter yang kurang baik dalam memberikan pelayanan. Berdasarkan analisa tersebut, maka variabel jaminan berpengaruh tidak signifikan terhadap kepuasan Pasien RJTL RSU St. Madyang di Kota Palopo. Oleh karena itu, variabel jaminan perlu mendapat perhatian khusus untuk lebih ditingkatkan terutama pada indikator yang membentuknya agar kepuasan Pasien RJTL RSU St. Madyang di Kota Palopo dapat ditingkatkan di masa akan datang.

Hasil penelitian ini sejalan dengan penelitian yang dilakukan oleh Mariaty Silalahi (2017) yang membuktikan bahwa variabel jaminan berpengaruh tidak signifikan terhadap kepuasan pasien. Namun penelitian ini tidak sejalan dengan penelitian yang dilakukan Junaedi (2012) membuktikan bahwa jaminan berpengaruh signifikan terhadap kepuasan nasabah. Begitu pula hasil penelitian Fatah (2015) juga membuktikan bahwa jaminan berpengaruh signifikan terhadap kepuasan pasien. Dengan demikian, penelitian ini dapat dijadikan acuan untuk penelitian lanjutan. Teori-teori tentang kualitas pelayanan ditinjau dari aspek jaminan (assurance) dan kepuasan pelayanan berlaku atau terbukti.

\section{Pengaruh empati terhadap kepuasan Pasien RJTL RSU St. Madyang}

Hasil pengujian secara parsial menunjukkan bahwa variabel empati berpengaruh positif dan signifikan terhadap kepuasan Pasien RJTL RSU St. Madyang di Kota Palopo. Hal ini mengindikasikan 
ada hubungan yang searah antara empati dengan kepuasan pasien rawat inap, dalam arti jika terjadi peningkatan empati, maka kepuasan pasien rawat inap juga akan meningkat. Variabel empati memberikan pengaruh signifikan terhadap kepuasan peserta dan menempati urutan ketiga dari variabel bebas yang telah diuji. Karena itu, variabel empati juga merupakan salah satu faktor penting dalam meningkatkan kepuasan Pasien RJTL RSU St. Madyang, sehingga perlu lebih ditingkatkan dengan memaksimalkan indikator-indikator yang membentuknya agar dapat meningkatkan kepuasan Pasien RJTL RSU St. Madyang di Kota Palopo. Adanya pengaruh signifikan variabel empati terhadap kepuasan peserta sangat ditentukan oleh peran indikator yang membentuknya, yaitu: ramah kepada Pasien RJTL RSU St. Madyang; Sopan dalam bertutur kata dengan Pasien RJTL RSU St. Madyang; dan Memberikan pelayanan yang adil kepada Pasien RJTL RSU St. Madyang. Dari ketiga butir indikator tersebut, maka indikator yang dominan dalam membentuk variabel empati adalah indikator sopan dalam bertutur kata dengan Pasien RJTL RSU St. Madyang, artinya Petugas RS Kesehatan sudah bersikap sopan dalam bertutur kata kepada Pasien RJTL RSU St. Madyang. Kemudian diikuti indikator ramah kepada Pasien RJTL RSU St. Madyang, artinya petugas telah bersikap ramah kepada semua Pasien RJTL RSU St. Madyang. Sedangkan indikator memberikan pelayanan yang adil kepada Pasien RJTL RSU St. Madyang memberikan proporsi terkecil dalam membentuk variabel empati, artinya petugas harus memberikan pelayanan yang adil dan tanpa membeda-bedakan Pasien RJTL RSU St. Madyang agar kepuasan Pasien RJTL RSU St. Madyang di Kota Palopo dapat ditingkatkan.

Penelitian ini didukung oleh teori Parasuraman (2001:40), setiap kegiatan atau aktivitas pelayanan memerlukan adanya pemahaman dan pengertian dalam kebersamaan asumsi atau kepentingan terhadap suatu hal yang berkaitan dengan pelayanan. Pelayanan akan berjalan dengan lancer dan berkualitas apabila setiap pihak yang berkepentingan dengan pelayanan memiliki adanya rasa empati (emphaty) dalam menyelesaikan atau mengurus atau memiliki komitmen yang sama terhadap pelayanan. Berdasarkan analisa tersebut, maka dapat disimpulkan bahwa variabel empati berpengaruh positif dan signifikan terhadap kepuasan Pasien RJTL RSU St. Madyang di Kota Palopo. Oleh karena itu, empati perlu ditingkatkan di masa akan datang. Hasil penelitian ini sejalan dengan penelitian yang dilakukan oleh Junaedi (2012) membuktikan empati berpengaruh signifikan terhadap kepuasan nasabah. Begitu pula hasil penelitian Mariaty Silalahi (2017) juga membuktikan empati berpengaruh signifikan terhadap kepuasan pasien. Namun, penelitian ini tidak sejalan dengan penelitian yang dilakukan oleh Fatah (2015) yang membuktikan bahwa variabel empati berpengaruh tidak signifikan terhadap kepuasan pasien. Dengan demikian, penelitian ini dapat dijadikan acuan untuk penelitian lanjutan. Teori-teori tentang kualitas pelayanan ditinjau dari aspek empati dan kepuasan pelayanan berlaku atau terbukti.

Berdasarkan uraian dan hasil analisis yang ditunjukkan pada bab sebelumnya, dapat disimpulkan hal-hal sebagai berikut:

1. Variabel tampilan fisik berpengaruh tidak signifikan terhadap kepuasan Pasien RJTL RSU St. Madyang di Kota Palopo, artinya tampilan fisik belum mampu meningkatkan secara signifikan kepuasan Pasien RJTL RSU St. Madyang.

2. Variabel kehandalan berpengaruh signifikan dan positif terhadap kepuasan Pasien RJTL RSU St. Madyang di Kota Palopo, artinya semakin baik atau strategi kehandalan maka cenderung akan meningkatkan kepuasan Pasien RJTL RSU St. Madyang.

3. Variabel ketanggapan berpengaruh signifikan dan positif terhadap kepuasan Pasien RJTL RSU St. Madyang di Kota Palopo, artinya semakin baik atau strategi ketanggapan maka cenderung akan meningkatkan kepuasan Pasien RJTL RSU St. Madyang.

4. Variabel jaminan berpengaruh tidak signifikan terhadap kepuasan Pasien RJTL RSU St. Madyang di Kota Palopo, artinya jaminan belum mampu meningkatkan secara signifikan kepuasan Pasien RJTL RSU St. Madyang.

5. Variabel empati berpengaruh signifikan dan positif terhadap kepuasan Pasien RJTL RSU St. Madyang di Kota Palopo, artinya semakin baik atau strategi ketanggapan maka cenderung akan meningkatkan kepuasan Pasien RJTL RSU St. Madyang.

6. Dari kelima variabel bebas yang digunakan dalam menentukan tingkat kepuasan Pasien RJTL RSU St. Madyang diatas, yang mempunyai pengaruh dominan dalam meningkatkan kepuasan Pasien RJTL di RSU St. Madyang Kota Palopo adalah Variabel Ketanggapan. 


\section{Saran}

Berdasarkan kesimpulan di atas, maka penulis memberikan beberapa saran yaitu seyogyanya faktor kehandalan, ketanggapan, dan empati dapat menjadi pertimbangan bagi pimpinan dalam meningkatkan kepuasan Pasien RJTL RSU St. Madyang di Kota Palopo, terutama indikator-indikator yang membentuk ketiga variabel yang memberikan pengaruh signifikan tersebut. Mengingat faktor ketanggapan yang memberikan pengaruh dominan terhadap kepuasan Pasien RJTL RSU St. Madyang, maka disarankan untuk dipertahankan terutama kebijakan yang terkait dengan indikator-indikator yang membentuknya.

\section{DAFTAR PUSTAKA}

Adikoesoemo, S., 2015. Manajemen Rumah Sakit. Pustaka Sinar Harapan, Jakarta.

Aditama, Y. Tjandra, 2013. Manajemen Administrasi Rumah Sakit. Universitas Indonesia, Jakarta.

Algifari. 2010. Analisis Regresi Teori, Kasus dan Solusi. Yogyakarta: BPFE.

Anoop, Rana, 1999. The Sky Limit Public Service. New Approach, Liberal Times, FNS.

Azwar, Azrul, H., 2016. Menjaga Mutu Pelayanan Kesehatan. Pustaka Sinar Harapan, Jakarta.

Barata, Atep Adya, 2013. Dasar-dasar Pelayanan Prima. PT Elex Media Komputindo. Jakarta

Barnes, James G. 2013. Rahasia Manajemen Hubungan Pelanggan. Yogyakarta :

Donalbedian, 2010. Exploration in Quality Assesment and Monitoring. Healt Administration, Press, Ann Arbor Michigan.

Fatah, 2015. Pengaruh Kualitas Pelayanan terhadap Kepuasan Pasien pada Rumah Sakit Umum Otorita Batam. Program Pasca Sarjana Universitas Gadjah Mada, Yogyakarta.

Gronroos, Michael, 1990. Perceived Service Quality Model. Published Ohio University Press, California.

Handi, Irawan, 2012, Prinsip Kepuasan Pelanggan, Elekmedia Komputindo, Jakarta.

Lerbin R. Aritonang R., 2015. Kepuasan Pelanggan. Pengukuran dan Penganalisisan dengan SPSS. Jakarta. PT. Gramedia Pustaka Utama.

Lupiyoadi, Rambat. 2011. Manajemen Pemasaran Jasa Teori dan Praktik. Jakarta : Salemba Empat.

Marcel, 2013. Management of Organization Behavior: Utility Human Resources. Aih Bahasa: Agus Darma, Manajemen Perilaku Organisasi: Pendayagunaan Sumber Daya Manusia. Erlangga, Jakarta.

Margaretha, 2013. Kualitas Pelayanan: Teori dan Aplikasi. Penerbit Mandar Maju, Jakarta.

Marknesis, T., 2009. Costomer Satisfaction and Beyond, Yogyakarta: Marknesis.

Martul, Shadiqqin, 2014. Implementasi Dimensi Kualitas Pelayanan Pelanggan. Penerbit Sinar Grafika, Jakarta.

Masri, Singarimbun dan Sofian Effendi. 2011. Metode Penelitian Survey. Jakarta : LP 3 ES.

Moenir, H.A.S., 2015. Manajemen Pelayanan Umum di Indonesia. Bumi Aksara. Jakarta.

Parasuraman, A., Zeithalm, V., dan Berry L., 1990. SERVQUAL: A Multiple item Scale for Measuring Consumer Perceptions of Service Quality. Journal of Retaliling.

Parasuraman, A. Valerie, 2001. Delivering Quality Service. The Free Press, New York (Diterjemahkan oleh Sutanto). Rangkuti, Freddy. 2013. Measuring Customer Satisfaction. Jakarta: Gramedia Pustaka Utama.

Ratminto dan Winarsih, A.S., 2015. Manajemen Pelayanan, Pengembangan Model Konseptual, Penerapan Citizen's Charter dan Standar Pelayanan Minimal. Yogyakarta: Penerbit Pustaka Pelajar.

Sari, I.D., 2018. Manajemen Pemasaran Usaha Kesehatan. Yogyakarta: Mitra Cendikia Press.

Siregar, C.J.P., 2014. Farmasi Rumah Sakit: Teori dan Penerapan, Penerbit EGC, Jakarta

Snok, 2011. Sistem Informasi Manajemen. Edisi Ketujuh, Prenhallindo, Jakarta.

Sugiyono, 2014. Statistik untuk Penelitian, Cetakan Kedua, Penerbit Alfabeta, Bandung.

Sunyoto, Hamingpraja, 2014. Jaminan Kualitas Pelayanan Pelanggan. Penerbit Liberty, Yogyakarta.

Supranto, J., 2017. Pengukuran Tingkat Kepuasan Pelanggan Untuk Menangkap Pangsa Pasar. Rineka Cipta, Jakarta.

Surajiyo, 2015. Ilmu Filsafat Suatu Pengantar. Bumi Aksara, Jakarta.

Susilo, M., 2010. Manajemen Pelayanan Sumber Daya Manusia. PT Andi Offset. Yigyakarta.

Sutojo, Heru, 2010. Prinsip-Prinsip Manajemen Keuangan, Edisi Kesembilan, Cetakan Pertama, Salemba Empat, Jakarta.

Trisnantoro, Laksono, 2015. Aspek Strategis Manajemen Rumah Sakit. Andi Offset, Yogyakarta.

Tjiptono, Fandy, 2010. Kepuasan Pelanggan dalam Pelayanan. Penerbit Salemba Empat, Jakarta.

Tjiptono, Fandy. 2014. Manajemen Jasa. Yogyakarta : Andi.

Yakobalis, 2010. Menjaga Mutu Pelayanan Rumah Sakit. Persi, Jakarta.

Zeithaml and Bitner, 2013. Delivering Quality Service. Balancing Customer Perceptions Expectations. The Free Press, New York. 